\title{
Manufactured Homes \\ Simulated \\ Thermal Analysis \\ and \\ Cost Effectiveness \\ Report
}

\author{
David Baylon \\ Bob Davis \\ Mike Kennedy \\ Mike Lubliner
}

\section{Ecotope, Inc. Washington State Energy Office}

May 17, 199()

DISCLAIMER

This report was prepared as an account of work sponsored by an agency of the United States Government. Neither the United States Government nor any agency thereof, nor any of their employees, makes any warranty, express or implied, or assumes any legal liability or responsibility for the accuracy, completeness, or usefulness of any information, apparatus, product, or process disclosed, or represents that its use would not infringe privately owned rights. Reference herein to any specific commercial product, prccess, or service by trade name, trademark, manufacturer, or otherwise does not necessarily constitute or imply its endorsement, recommendation, or favoring by the United States Government or any agency thereof. The views and opinions of authors expressed herein do not necessarily state or reflect those of the United States Government or any agency thereof.

Prepared for Bonneville Power Administration under Contract Number DE-AM79-87BP35738

Task Order Number AT989773

\section{MASTER}




\section{Table of Contents}

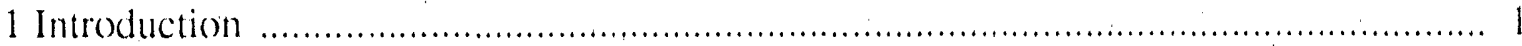

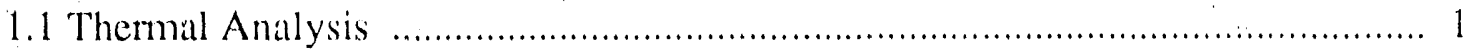

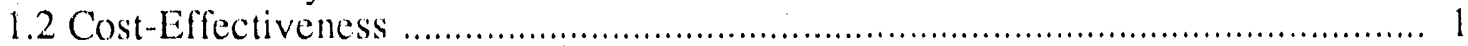

1.3 Report Organization ...............................................................................

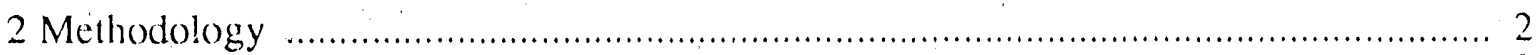

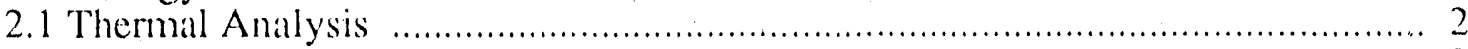

2.1.1 Heat Loss Analysis .......................................................................... 2

2.1.2 Engineering Simulations …….............................................................. 2

2.2 Cost-Effectiveness Analysis .............................................................................. 3

2.2.1 RCDP Cost-Effectiveness ................................................................. 3

2.2.2 Optimum Conservation Package ……..................................................... 3

2.3 Presentation of Analysis ............................................................................... 4

3 Thermal Analysis: Component Performance and Heat Loss Rates ............................ 5

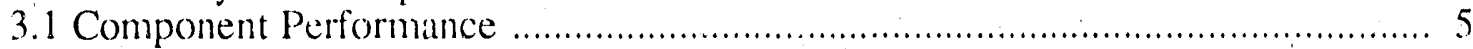

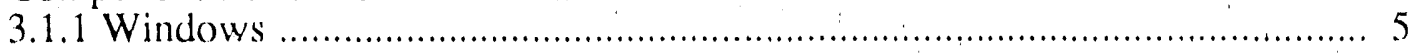

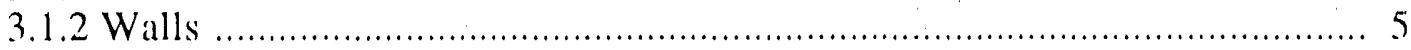

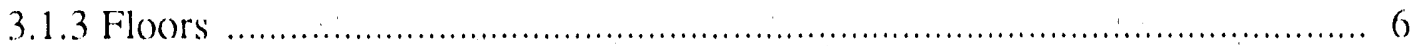

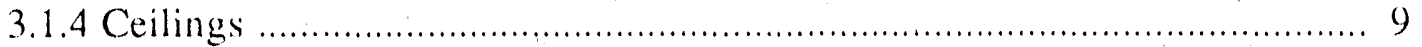

3.1.5 Heat Pumps and Duct Systems .......................................................... 12

3.2 Overall Building Heat Loss Rate ................................................................... 12

3.2.1 SGC Compliance ............................................................................ 14

3.2.2 Heat Loss Rates .............................................................................. 15

4 Thermal Performance: Energy Savings .................................................................. 18

4.1 Simulation Assumptions ....................................................................... 18

4.2 Weather Sites ...................................................................................... 18

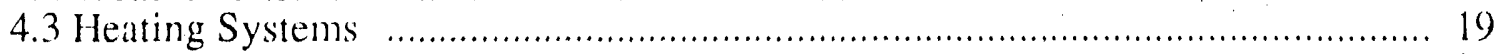

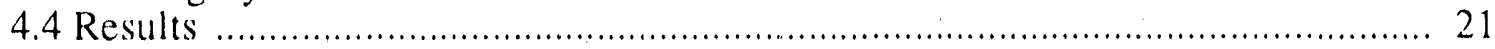

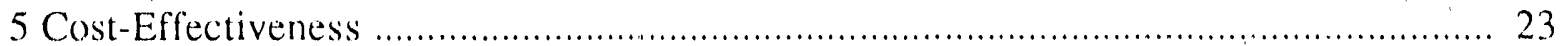

5.1 Assumptions and Life Cycle Cost Adjustments .................................................... 23

5.2 Cost-Benefit Analysis .................................................................................. 23

5.2.1 Package Costs ...................................................................................... 23

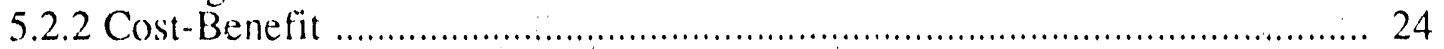

5.2.3 Consumer Benefits ....................................................................... 25

5.3 Optimum Conservation Packalges ................................................................. 26

5.3.1 Optimization Assumptions ..................................................................... 26

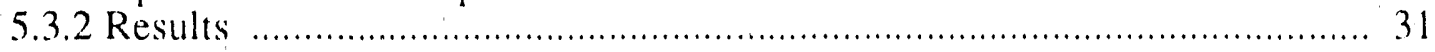

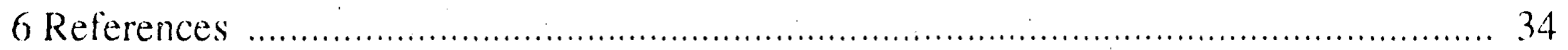

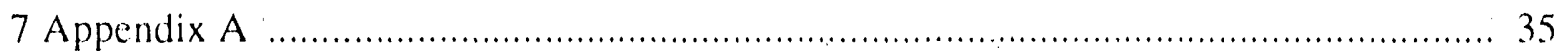

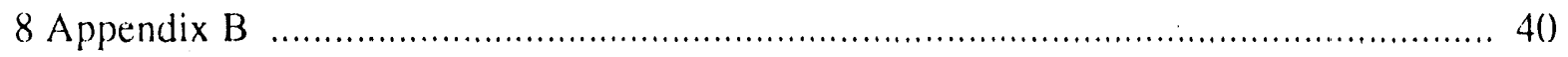

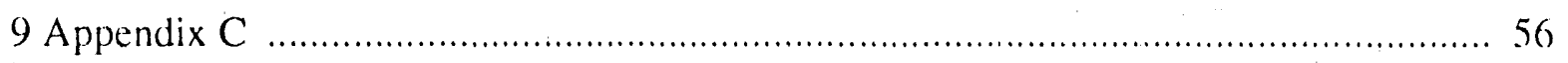




\section{Table of Figures}

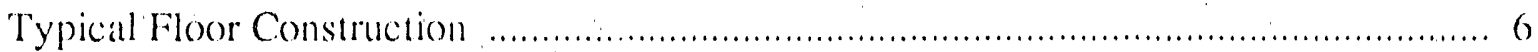

Baffle as Part of Ceiling lnsulation Strategy ........................................................ 10

Stepped Batt Ceiling Insulation Strategy ............................................................ 10

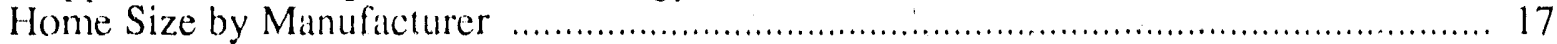

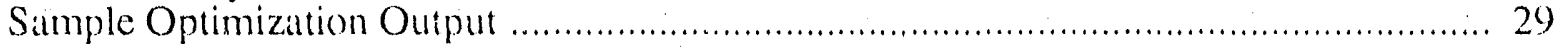




\section{Table of 'Tables}

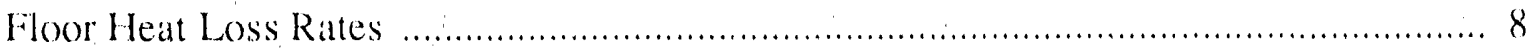

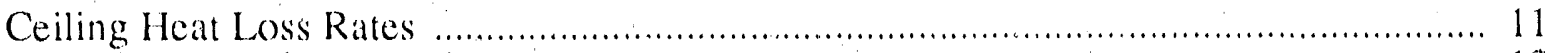

Most Common Conservation Meatsures ............................................................ 13

Component Heat Loss by Climate Zone ............................................................ 14

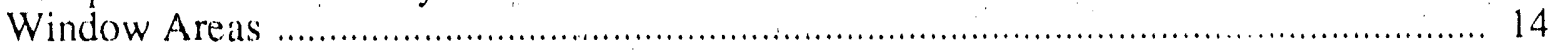

Heat Loss Rates by Manufacturer ............................................................... 15

Heat Loss Rates by Climate Zone ..................................................................... 16

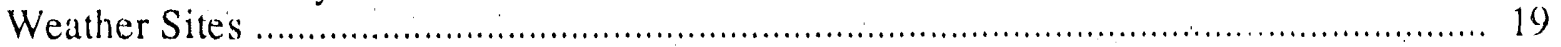

Simulated Heating Energy Performance and Savings ........................................... 21

Simulated Annual Energy Savings by Manufacturer .............................................. 22

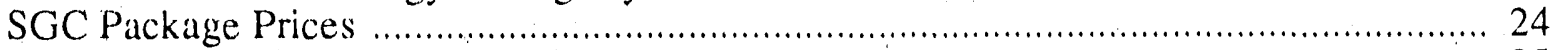

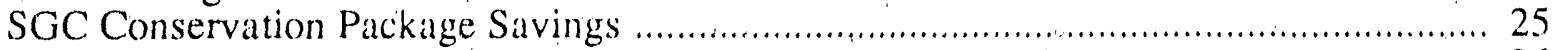

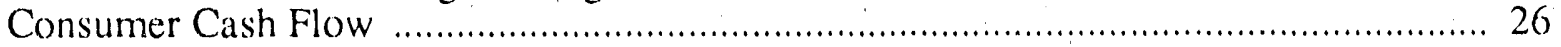

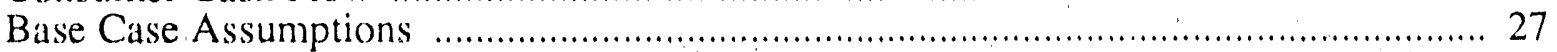

Conservation Options for Cost Optimization .....................................................

Optimum Package with Conventional Floors .................................................. 32

Optimum Package with Optimum Floor Construction ............................................... 32 


\section{Executive Summary}

In 1988 and 1989, 150 manufactured homes were built to comply with Super Good Cents (SGC) specifications adapted from the existing specifications for site-built homes under the Residential Construction Demonstration Project (RCDP). Engineering calculations and computer simulations were used to estimate the effects of the SGC specifications on the thermal performance of the homes. These results were compared with consumer costs to establish the cost-effectiveness of individual measures. The most cost-effective measures were combined in an optimum conservation package.

Heat loss U-factors for windows, walls, floors and ceilings were established using the standard ASHRAE parallel heat flow method. Adjustments were made to the U-factors to take into account the actual construction practices used in the manufactured homes (such as stepped batt placement in attics and the location of an uninsulated heating duct between two layers of insulation in the floors). These adjustments resulted in higher U-factors for ceilings and floors than assumed at the time the homes were approved as meeting the SGC specifications. As a result, except for those homes which includid heat pumps, most of the homes did not meet the SGC compliance standards. Nonetheless, these homes achieved substantial reductions in overall heat loss rate (UA) compared to UAs estimated for the same homes using the standard insulation packages provided by the manufacturers in the absence of the RCDP program. Homes with conventional electric furnaces showed a $35 \%$ reduction in total UA while homes with heat pumps had a $25 \%$ reduction. A regression analysis showed no significant relationship between climate zone, manufacturer and UA.

A modified version of the SUNDAY building simulation program which simulates duct and heat pump performance was used to model the thermal performance of each RCDP home as built and the same home as it would have been built without the SGC specifications (base case). Standard assumptions were used for thermostat setpoint, thermal mass, internal gains and infiltration rates. The only variations were UAs (based on the engineering calculations described above) and weather sites (which were assigned to match the sites on which the homes were located). The SUNDAY program calculated a predicted annual heating energy requirement for each RCDP and base case home. The difference between these two predictions was the energy savings. The results confirmed the pattern seen in the UA-only analysis. There was little difference in energy savings between manufacturers except where related to house size. Higher energy savings were found in the colder climate zones, 2 and 3, because larger energy requirements resulted in larger savings, given the same UA. The overall savings for RCDP homes was $51 \%$ for all homes- $44 \%$ for homes with forced air furnaces and $71 \%$ for homes with heat pumps.

We applied a levelized cost factor to the present value of the entire SGC package over the life of each home to arrive at a cost-henefit ratio expressed in $\$ / k$ Wh saved. The SGC package cost per manufacturer derived in an earlier report (Baylon, Lubliner \& Davis, 199()) was converted to a present value retail cost using the following assumptions; a life expectancy of 45 years for all envelope measures except windows, 30 years for windows, 15 years for heat pumps, and an annual real discount rate of $3 \%$. The levelized costs are shown in Table A.1.

Financial benefits to the consumer were calculated by comparing the cost of implementing the conservation measures to the savings in heating energy costs. For homes without heat pumps, the net first year cash flow is $\$ 125$ per year when the SGC incentive is taken into account. In the absence of the incentive, the consumer does not see a positive cash flow at current energy costs. Homes with heat pumps did not demonstrate a positive cash flow either with or without the incentive; however, cooling benefits and costs were not examined in this analysis. 


\begin{tabular}{|c|c|c|c|c|c|c|}
\hline \multicolumn{7}{|c|}{$\begin{array}{c}\text { Table A.1 } \\
\text { SGC Conservation Package Savings }\end{array}$} \\
\hline $\begin{array}{l}\text { Climate } \\
\text { Zone }\end{array}$ & $\begin{array}{l}\text { Heating } \\
\text { System } \\
\text { Type }\end{array}$ & $\mathbf{N}$ & $\begin{array}{c}\text { Average } \\
\text { Annual } \\
\text { kWh } \\
\text { Savings }\end{array}$ & $\begin{array}{c}\text { Average } \\
\text { Present } \\
\text { Value } \\
\text { Retail } \\
\text { Price }(\$)\end{array}$ & $\begin{array}{l}\text { UA/ft }{ }^{2} \\
\text { (living } \\
\text { area) }\end{array}$ & $\begin{array}{c}\text { Levelized } \\
\text { Cost } \\
\text { of } \\
\text { Savings } \\
(\$ / k W h)\end{array}$ \\
\hline \multirow[t]{2}{*}{1} & Elect & 60 & 6021 & 3851 & .223 & .027 \\
\hline & $\mathrm{HP}$ & 24 & 10869 & 9327 & .267 & .036 \\
\hline \multirow[t]{2}{*}{2} & Elect & 51 & 7963 & 455.2 & .218 & .025 \\
\hline & $\mathrm{HP}$ & 8 & 12473 & 9716 & .271 & .032 \\
\hline \multirow[t]{2}{*}{3} & Elect & 5 & 11000 & 4916 & .216 & .019 \\
\hline & $\mathrm{HP}$ & 0 & - & $7 \quad \ldots$ &.- & $\ldots$ \\
\hline \multirow[t]{2}{*}{ ALL } & Elect & 116 & 6725 & 4205 & .221 & .026 \\
\hline & $\mathrm{HP}$ & 32 & 11270 & 9425 & .268 & .035 \\
\hline TOTAL & & 148 & 7707 & 5330 & .231 & .028 \\
\hline
\end{tabular}

SUNDAY simulations were used to assess individual conservation measures applied to a prototype building to determine the contribution of each measure to the cost-effectiveness of an entire package. We used a cost ceiling of 52 mills for all measures. Table A.2 shows the area-normalized cost and levelized cost of energy saved for each measure applied to the prototype.

Fifteen separate packages were analyzed using different combinations of conservation measures for each of the three climate zones. Although the inclusion of the heat pump saved substantially more energy than any other measure, it was not cost-effective in Climate Zones 1 and 2.

Argon-filled windows were the preferred window option, producing twice the savings achirved by plain vinyl windows. Except in the coldest climates, attic and ceiling insulation optimized at about R-30, somewhat below the SGC specifications. The tise of a cardboard baffle (which compresses insulation at the ceiling edges) improves cost-effectiveness, as does the use of blow-in insulation. For manufactured homes built using conventional floor construction methods, the optimum package uses an R-22 belly blanket and R-22 ciavity insulation in Zones 2 and 3 and $R-11$ cavity insulation and R-11 belly blanket for heat pump cases. Using an improved floor irisulation strategy (in which the floor insulation is cut in beneath the heating duct) improves floor insulation performance dramatically. Duct insulation is by far the most cost-effective option, increasing performance about $16 \%$ at a minimal cost, and should be a required part of SGC packages. 


\begin{tabular}{|c|c|c|c|c|c|c|}
\hline & $\begin{array}{l}\text { Conse } \\
\text { for } \mathrm{Ce}\end{array}$ & $\begin{array}{l}\text { able A.2 } \\
\text { vation Options } \\
\text { Optimization }\end{array}$ & & & & \\
\hline & & $\begin{array}{c}\text { U- } \\
\text { factor }\end{array}$ & & $\underset{\text { Clir }}{\text { Mil }}$ & $\begin{array}{l}\text { s/kwll } \\
\text { nate } \mathrm{Z}_{0}\end{array}$ & \\
\hline Component & Option & $\left(\mathrm{Btu} / \mathrm{hr}-\mathrm{ft}^{2}\right)$ & $\left(\$ / \mathrm{fi}^{2}\right)$ & 1 & 2 & 3 \\
\hline Window & $\begin{array}{l}\text { Vinyl Frame } \\
\text { Argon Filled Vinyl Frame }\end{array}$ & $\begin{array}{l}.45 \\
.39\end{array}$ & $\begin{array}{l}10.82 \\
12.27\end{array}$ & $\begin{array}{l}39.9 \\
27.7\end{array}$ & $\begin{array}{l}29.3 \\
20.0\end{array}$ & $\begin{array}{l}25.2 \\
17.1\end{array}$ \\
\hline Wall & $\begin{array}{l}\mathrm{R}-19 \\
\mathrm{R}-22 \\
\end{array}$ & $\begin{array}{l}.062 \\
.060 \\
\end{array}$ & $\begin{array}{l}.23 \\
.31 \\
\end{array}$ & $\begin{array}{r}9.5 \\
46.1 \\
\end{array}$ & $\begin{array}{r}7.3 \\
32.8 \\
\end{array}$ & $\begin{array}{r}6.3 \\
28.1 \\
\end{array}$ \\
\hline Floor & $\begin{array}{ll}\text { R-11 } & \text { Belly } \\
\text { R-11 } & \text { Belly, R-11 Cavity } \\
\text { R-11 } & \text { Belly, R-22 Cavity } \\
\text { R-22 } & \text { Belly, R-22 Cavity } \\
\text { R-11 } & \text { Cut In } \\
\text { R-19 } & \text { Cut In } \\
\text { R-22 } & \text { Cut in } \\
\text { R-33 } & \text { Cut In } \\
\end{array}$ & $\begin{array}{l}.088 \\
.053 \\
.047 \\
.036 \\
.066 \\
.048 \\
.044 \\
.036\end{array}$ & $\begin{array}{l}.09 \\
.35 \\
.61 \\
.87 \\
.09 \\
.28 \\
.35 \\
.61\end{array}$ & \begin{tabular}{r|}
5.2 \\
9.7 \\
37.5 \\
53.6 \\
4.9 \\
10.5 \\
19.7 \\
38.6
\end{tabular} & $\begin{array}{r}3.9 \\
7.8 \\
28.8 \\
34.0 \\
3.7 \\
7.7 \\
14.5 \\
27.8\end{array}$ & $\begin{array}{r}3.4 \\
6.8 \\
24.9 \\
28.7 \\
3.2 \\
6.6 \\
12.5 \\
23.9\end{array}$ \\
\hline $\begin{array}{l}\text { Ceiling } \\
\text { (Attic) }\end{array}$ & $\begin{array}{l}\text { R-19 Batt } \\
\text { R-30) Batt } \\
\text { R-38 Batt } \\
\text { R-49 Batt } \\
\text { R-52 Batt } \\
\text { R-49 Blown In } \\
\end{array}$ & $\begin{array}{l}.055 \\
.043 \\
.(040 \\
.036 \\
.035 \\
.026 \\
\end{array}$ & $\begin{array}{l}.13 \\
.40 \\
.60 \\
.88 \\
.95 \\
.44 \\
\end{array}$ & $\begin{array}{r}12.7 \\
24.3 \\
78.4 \\
82.0 \\
82.4 \\
2.8 \\
\end{array}$ & $\begin{array}{r}9.5 \\
18.2 \\
141.7 \\
148.2 \\
148.9 \\
2.0 \\
\end{array}$ & $\begin{array}{r}8.2 \\
15.6 \\
48.6 \\
124.3 \\
125 .(0 \\
1.8 \\
\end{array}$ \\
\hline $\begin{array}{l}\text { Ceiling } \\
\text { (Vaulted) }\end{array}$ & $\begin{array}{l}\text { R-19 Batt } \\
\text { R-3() Batt } \\
\text { R-38 Batfle } \\
\text { R-38 Blown In }\end{array}$ & $\begin{array}{l}.055 \\
.043 \\
.041 \\
.035\end{array}$ & $\begin{array}{l}.13 \\
.44 \\
.62 \\
.31\end{array}$ & $\begin{array}{l}12.7 \\
3(0.5 \\
7(0.5 \\
10.3\end{array}$ & $\begin{array}{r}9.5 \\
22.8 \\
5() .6 \\
7.7\end{array}$ & $\begin{array}{r}8.2 \\
19.6 \\
43.5 \\
6.6\end{array}$ \\
\hline Ducts & $\begin{array}{l}\text { R.-4 } \\
\text { Sound* }\end{array}$ & & $\begin{array}{l}\text { 31./home } \\
10 . \text { /home }\end{array}$ & $\begin{array}{l}1.77 \\
0.77\end{array}$ & $\begin{array}{l}1.16 \\
0.52\end{array}$ & $\begin{array}{l}1.01 \\
0.45\end{array}$ \\
\hline $\begin{array}{l}\text { Heating } \\
\text { System }\end{array}$ & Heat Pump & & $5431 / \mathrm{home}$ & $1(1) 2.2$ & 56.3 & 49.4 \\
\hline
\end{tabular}




\section{Introduction}

This report analyzes the simulated themal performance and cost-effectiveness of conservation measures installed in manufactured homes built under the Residential Construction Demonstration Project (RCDP) Manufactured llomes Program sponsored by the Bonneville Power Administration (BPA). In 1988 and 1989, 150 homes were built under this project by 8 manufacturers located in Washington and Oregon. The homes were built using Super Good Cents (SGC) specifications adapted from the existing specifications tor site-built homes. These specifications set performance standards for building envelope components (doors, windows, ceilings, floors and walls) and ventilation systems.

We used engineering calculations and simulations to estimate the effects of the SGC specifications on the thermal performance of the homes. These methods permit analysis of the effects of various measures. Thus, they can be used to evaluate alternative packages of measures with the goal of developing an optimum package containing the most cost effective and thermally efficient conservation measures which can be used in manufactured homes. Empirical data on actual energy use is not appropriate for this purpose because the effects of interaction between conservation measures and occupant behavior are masked. However, in a future study, we will use submetered data collected from these homes to refine and confirm the results of the engineering analysis.

\subsection{Thermal Analysis}

We used the standard parallel heat flow method (ASHRAE, 1989) to establish the heat loss U-factors for each building component. Some adjustments were necessary to the nominal U-factors to compensate for the actual methods used by the manufacturers to meet the specifications. A steady-state heat loss rate was determined for each home using the results of the component analysis and an assumed building infiltration rate. We used the SUNDAY building load analysis program to simulate the thermal performance of each home, using the heat loss rate and other parameters (heating and duct system description, thermostat setpoint, building mass, local climate data, etc.) as inputs. The version of SUNDAY we used is modified to take into account the impact of forced air heating systems and heat pumps. The SUNDAY simulation was run twice on each home, once for the home as built under the RCDP program and once for the same home in the absence of any SGC conservation options (base case). The difference between the two was the amount of energy saved.

\subsection{Cost-Effectiveness}

This report evaluates the cost-effectiveness of the various conservation measures by comparing the energy savings estimated in the thermal analysis with the standardized component costs developed in an earlier report (Baylon, Lubliner \& Davis, 199()). Since the purpose of this analysis is to determine the most cost-effective conservation measures for manufactured homes--even if they were not used by manufacturers in this project--we also conducted an optimization analysis. This involved assessing individual conservation measures, sequentially installed in a prototype building, to determine the most cost-effective combination.

\subsection{Report Organization}

This report contains five sections. The first section introduces the report and summarizes the goals of the analysis. The second section discusses the methodologies used in both the thermal analysis and the cost-effectiveness analysis. The third section describes the U-factor corrections and evaluates the component conservation measures. The fourth section details the results of the simulation analysis and energy savings estimates. The fifth section documents the cost-effectiveness of the individual components and packages. 


\section{Methodology}

\subsection{Thermal Analysis}

\subsubsection{Heat Loss Analysis}

Thermal analysis was based on a standard engineering method for determining parallel heat flow and thus total heat loss rate (U-factor). This method requires detailed evaluation of individual components based on drawings, direct observation of manufacturing techniques and reports from the manufacturers who participated in the program. The basic mothod is described in the 1989 ASHRAE Fundamentals Handbook, the SGC Heat Loss Reference Manual (Baylon and Heller, 1988) and other engineering texts.

The parallel heat flow method was applied to all components of the building envelope and individualized for each manufacturer. The methods used by manufacturers for insulating the ceilings and floors varied significantly from the assumptions and methodologies listed in the original SGC specifications. For these two components, we made substantial alterations in the nominal SGC U-factors to take into account the methods actually used by the manufacturers.

We generated two building heat loss rates for each home. One was a total conductive heat loss rate which ignored all equipment and duct effects in the floor system. The second was a modified heat loss rate which included a detailed correction for the heating duct systems as installed.

We also generated heat loss rates for each base case home. The base case home was identical to the RCDP home except it did not contain any of the SGC conservation measures. We determined the base case components and insulation levels using information on the basic model for each home provided by the manufacturers in response to the cost data questionnaires used in the previous report (Weakley, Eckert \& Lee, 199()).

\subsubsection{Engineering Simulations}

We used the total building heat loss rate (UA) and the window, door and floor specifications as inputs to the building simulation program.

We used SUNDAY for the thermal simulations rather than WATTSUN, the standard tool used for performance assessments in the SGC program. SUNDAY is a numerical simulation program which uses local weather data to simulate the effect of climate on building heating requirements. WATTSUN is a simpler tool which uses an equation derived from numerous SUNDAY simulations to estimate thermal performance of a building. Since SUNDAY was the basis of WAT'TSUN, the results of both programs will agree (within the range of acceptable statistical error) given identical inputs. Howewr. many important assumptions are built in to the WATTSUN program and cannot be changed to reflect actual conditions in a particular home. These assumptions include thermostat setpolnt, occupant-induced heat gains and (to some extent) building size. Thus, SUNDAY is more flexible than WATTSUN in simulating equipment and permitting varied assumptions on building operating characteristics. Using SUNDAY will allow a better comparison to the data on submetered energy use, which will be analyzed in future reports on these homes. 
SUNDAY simulations were done for each base case and RCDP home, using the same assumptions used in the WATTSUN runs: $65^{\circ} \mathrm{F}$ thermostat setpoint, $3(0)(0) \mathrm{Btu} / \mathrm{hr}$ of internal thermal gains, a mass level appropriate to light-frame construction and $0.35 \mathrm{Air}$ Changes per Hour (ACH). Since we had no data on the orientation of the buildings, we used the same assumptions as the WATTSUN runs and divided the window area evenly among the four cardinal orientations (North, East, South and West). These assumptions will be revised once we have data on actual building configuration and operation from field investigations. We assumed the duct systems in the base case homes were identical in placement and sizing to those in the RCDP homes. The only differences were in insulation levels, window specifications and heating systems (for those homes in which heat pumps were installed as an SGC option).

The difference between the heating energy required by the base case and RCDP home was considered energy savings due to the SGC specifications. We also considered the impact of equipment on heat loss rate. Heat pump savings were calculated separately for the 32 homes in which heat pumps were installed as part of the SGC package.

\subsection{Cost-Effectiveness Analysis}

Cost-effectiveness was calculated using the BPA levelizing procedure for conservation programs (James, 199()). We used the following measure lifetime assumptions: a building life of 45 years, a 30 year life for windows; and a 15 year life for heat pumps. For windows and heat pumps, we estimated that a full cost replacement would occur as often as necessary to make them last as long as the building envelope ( 4.5 years). Thus we assumed that windows would be replaced with new windows at 30 years and the heat pump would be replaced twice, once at 1.5 years and again at 3() years. The entire cost stream was discounted to its present value with a $3 \%$ annual real discount rate.

\subsubsection{RCDP Cost-Effectiveness}

We computed a present value retail cost for the SGC package used for each RCDP home; this cost included adjustments for the replacement costs of heat pumps and windows. Thus the retail price of the conservation package escalated somewhat over the standardized package price calculated in the cost analysis report (Baylon, Lubliner \& Davis, 199()). The present value package cost was then divided by the energy savings found in the SUNDAY analysis to generate an estimated cost of heating energy saved (in $\$ / \mathrm{kWh}$ ) for each home.

\subsubsection{Optimum Conservation Package}

To review the cost-effectiveness of each conservation measure, we developed five optimum cost-benefit packages which were evaluated separately. Two packages (one with a heat pump and one without) used the measures detailed in the SGC specifications and actually used by the manufacturers in the RCDP. TwO packages (one with a heat pump and one without) used an alternative floor insulation strategy. Some RCDP packages included blow-in ceiling insulation. We reviewed this as a separate package for homes without heat pumps since the manufacturers that used blow-in ceiling insulation did not install heat pumps in their homes. 
A typical manufictured home was selected from the database for use as a prototype base case home. We selected typical insulation levels using the information provided by the manufacturers. Using the component areas from the prototype home and the typical base insulation specifications, we derived an initial heat loss rate and ran a SUNDAY simulation to estimate the amount of energy required to heat the prototype. 'Then, each potential conservation measure was added to the prototype individually and an energy savings was derived by comparing the new estimate of energy used with the energy predicted in the base case. A cost-benefit ratio $(\$ / \mathrm{kWh})$ was calculated based on the present value cost and incremental energy savings of each measure. The most cost-effective measure was then added to the prototype to form a new base case. All the remaining options were then re-run against the "revised" prototype base case. This process was repeated with a cost-benefit ratio calculated for each successive measure to avoid double counting of savings. For those packages without heat pumps in the base case, the heat pump was added at that cost-benefit level where it competed with the other conservation measures.

The entire process was repeated using heat pumps as the base case heating system. A cost-benefit ratio was computed for each measure in the context of the reduced heating load caused by using the heat pump at the start.

\subsection{Presentation of Analysis}

The procedures described above were applied to each home. The detailed data derived from the Manufactured Homes Cost Data Collection database (Weakley, Eckert \& Lee, 1990), SUNDAY runs and engineering analysis are contained in a working database. This report contains summaries of the results. 


\section{Thermal Analysis: Component Performance and Heat Loss Rates}

The thermal analysis was conducted in two parts. During the first part, which is summarized in this section, we looked at both component performance and overall heat loss rates. This included reviewing and revising the UAs estimated by the WATTSUN runs. During the second part, we used the SUNDAY simulation program to predict the thermal performance of the homes. 'lihe following section, Section 4, describes the results of these simulations.

\subsection{Component Performance}

Buildings lose heat through walls, floors, ceilings, windows, doors and infiltration.

SUNDAY uses the heat loss rates (U-factors) for each of these components to determine the overall heat loss rate (UA) of a building.

\subsubsection{Windows}

Four types of windows were used to meet the SGC specifications:

1) a vinyl frame window with a tested $U$-factor of 0.44 ;

2) an argon-filled, vinyl frame, double-glazed window with a tested U-factor of (0.39;

3) a thermally broken aluminum-frame window with low-E coating with a tested U-factor of 0.45 ;

4) an interior storm window added to the window already used by the manufacturers as their base case window specification, with a tested U-factor of 0.43 .

The base case window was a non-thermally-broken aluminum frame window with a U-factor of (0.75. For some homes where heat pumps were used as part of the SGC qualification, this base case window was part of the SGC package.

The window U-factors used in this analysis were based on tests conducted by window manufacturers according to American Architectural Manufacturers Association (AAMA) standards.

\subsubsection{Walls}

Almost all walls were framed with $2 \times 6$ studs and insulated with R-19 or R-22 batis. There were two exceptions. In one case, an R-25 batt was crushed into a $2 \times 6$ wall and in another case, a strap wall was used in an effort to bring the R-factor to a higher level. We did a thermal analysis for this latter case but did not include this house in the cos:-benefit analysis since we did not have sufficient data to establish the cost-effectiveness or even wholesale price of this measure.

The U-factors associated with the wall options were computed using a standard heat loss spreadsheet developed for the SGC Heat Loss Reference (Baylon \& Heller, 1988). This spreadsheet accounts for all characteristics of the parallel heat flow in walls (framing fraction, insulation batt compression and construction components) and provides a reasonably accurate engineering value for the overall wall U-factor.

Using the parallel heat flow method described in the SGC reference manual and the SGC spreadsheet, we computed an overall U-factor of 0.062 for $R-19$ walls and a $U$-factor of 0.06() for R-22 walls. 


\subsubsection{Floors}

Because of the construction methods used in manufactured homes, the floor was the most complex component in the analysis.

The RCDP homes are all double-wide manufactured homes which means they are made up of two sections each approximately 14 feet wide. Each section is constructed on a steel carriage which is used to transport the home down the highway and then serves as a foundation for the home.

In the plant, the steel structure is welded together and a layer of insulation called a belly tlanket is stretched over the entire structure. Heating ducts, one per section, each running the full length of the house in the center of each section, are laid between the main steel I-beams on top of the belly blanket. Heat registers are cut into the tops of these ducts and boots are added as desired for individual rooms.

The floors are iramed on top of the I-beams and the belly blanket. The floor is usually framed wis $2 \times 6$ studs, although one manufacturer used $2 \times 8$ s. In the base case construction, no floor joist insulation is added--the $R$-value of the belly blanket represents the cotal floor insulation value. In the base case, this blanket is either a 3-1/2 inch R-11 batt or a $2-1 / 2$ inch R-7 batt. In albout two thirds of the RCDP homes, additional insulation was added to the belly blanket. Figure 3.1 illustrates the typical floor construction of a manufactured home and the location of the insulation as installed.

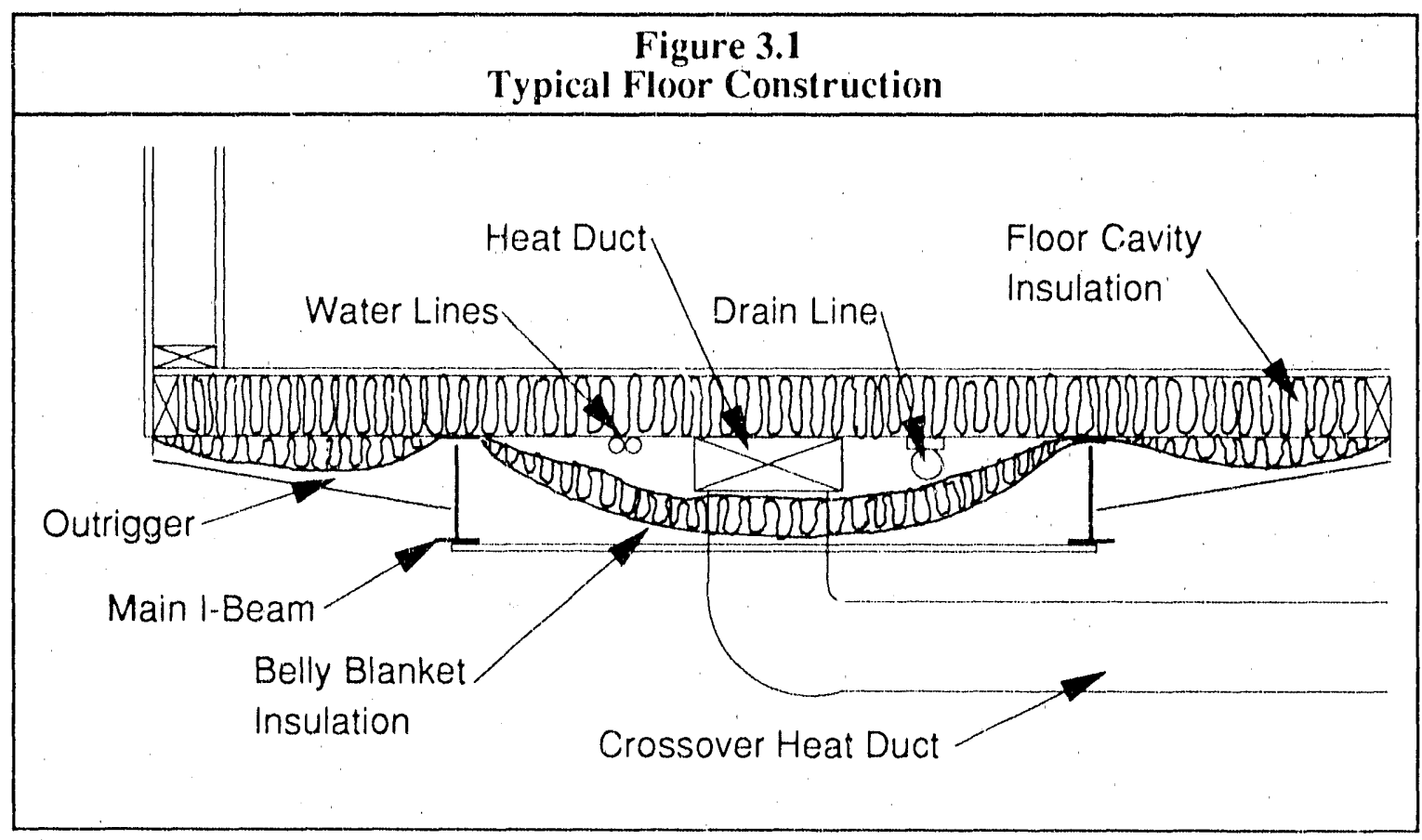

The SGC specifications required an additional layer of insulation placed between the floor joists in the floor framing. However, the floor construction of manufactured homes differs considerably from site-built homes and the performance of these floors differs significantly from the steady-state performance assumed in SGC specifications.

Manufactured homes use a forced-air heating system with supply ducts located between the floor joists and the belly blanket. One manufacturer (who built 29 homes) insulated 
the ducts; however, in the rest of the cases, the ducts were not insulated. When uninsulated heating system ducts are located in the space between the belly blanket and the floor insulation, this space is actually maintained at a temperature very similar to the house temperature. As a result that portion of the floor insulation immediately above the duct is not effective in reducing the overall heat loss rate. A steady-state analysis would mistakenly give credit for the $\mathrm{R}$-value of this floor insulation equal to the value of the insulation itself plus the appropriate parallel heat flow adjustments for surface films and framing.

Our analysis corrects the floor U-factor for the effect of the uninsulated ducts. We also corrected the floor U-factor to take into account the reduced value of the belly blanket where it is compressed by the steel structure against the bottom of the floor framing.

Corrections were made in three stages. First, we calculated a revised steady-state heat loss rate for each component of the floor insulation system. This was done using standard parallel heat flow methods that took into account the compression of the belly blanket and the insulation in the floor joists (where appropriate). Second, we used a duct simulation program to adjust the steady-state U-factor. Third, we used the revised steady-state U-factor and the duct effects as inputs to a SUNDAY simulation. The combined correction was then applied to all 150 homes.

The impact on floor $U$-factors is shown in Table 3.1. This table represents a reasonable approximation of the impact of the duct insulation on floor conductivity. The values shown here were calculated for a protoype manufactured home. (See section 5.3.1 for a discussion of this home and Appendix A for building plans.) The duct U-factors are calculated for the prototype house in Seattle (Climate Zone 1). The "SGC steady-state" U-factors were taken from the SGC specifications. As can be seen, the revisions in steady-state and duct-influenced U-factors result in an increase in the heat loss rate of the floor system above that which would be predicted using the nominal SGC U-factors.

Table 3.1 also includes the steady-state U-factor for an alternative floor insulation strategy in which the insulation is extended beneath the heating duct (the "cut-in" strategy). This strategy was assessed in the optimization analysis. 


\begin{tabular}{|c|c|c|c|c|c|}
\hline \multicolumn{6}{|c|}{$\begin{array}{c}\text { Table } 3.1 \\
\text { Floor Heat Loss Rates } \\
\text { (U-factors) } \\
\left(\mathrm{Btu} / \mathrm{hr}-\mathrm{ft}^{2}\right)\end{array}$} \\
\hline \multicolumn{2}{|c|}{$\begin{array}{l}\text { Nominal } \\
\text { Insulation } \\
\text { R-Value }\end{array}$} & \multirow[b]{2}{*}{$\begin{array}{c}\text { SCC } \\
\text { Steady-state }\end{array}$} & \multirow{2}{*}{$\begin{array}{c}\text { Revised } \\
\text { Steady-state }\end{array}$} & \multirow{2}{*}{$\begin{array}{l}\text { Corrected } \\
\text { Unwrapped } \\
\text { duct }\end{array}$} & \multirow{2}{*}{$\begin{array}{l}\text { Corrected } \\
\text { R-4 duct } \\
\text { insulation }\end{array}$} \\
\hline Belly & $\begin{array}{l}\text { Floor } \\
\text { Joist }\end{array}$ & & & & \\
\hline $\begin{array}{l}7 \\
11 \\
22\end{array}$ & () & $\begin{array}{l}.095 \\
.081 \\
.065\end{array}$ & $\begin{array}{l}.098 \\
.081 \\
.063\end{array}$ & $\begin{array}{l}.123 \\
.100 \\
.076\end{array}$ & $\begin{array}{l}.107 \\
.088 \\
.068\end{array}$ \\
\hline $\begin{array}{l}7 \\
11 \\
22\end{array}$ & 11 & $\begin{array}{r}.046 \\
.041 \\
\cdots\end{array}$ & $\begin{array}{l}.049 \\
.045 \\
.039\end{array}$ & $\begin{array}{l}.079 \\
.068 \\
.062\end{array}$ & $\begin{array}{l}.059 \\
.053 \\
.047\end{array}$ \\
\hline $\begin{array}{l}7 \\
11 \\
22\end{array}$ & 19 & $\begin{array}{c}.036 \\
.033 \\
--\end{array}$ & $\begin{array}{l}.039 \\
.036 \\
.031\end{array}$ & $\begin{array}{l}.072 \\
.061 \\
.050\end{array}$ & $\begin{array}{l}.050 \\
.044 \\
.038\end{array}$ \\
\hline $\begin{array}{l}7 \\
11 \\
22\end{array}$ & 22 & $\begin{array}{c}.032 \\
.030 \\
-\end{array}$ & $\begin{array}{l}.034 \\
.032 \\
.029\end{array}$ & $\begin{array}{l}.068 \\
.059 \\
.048\end{array}$ & $\begin{array}{l}.045 \\
.041 \\
.036\end{array}$ \\
\hline $\begin{array}{c}7 \\
11 \\
22\end{array}$ & 25 & $\begin{array}{c}.030 \\
.028 \\
--\end{array}$ & $\begin{array}{l}.032 \\
.030 \\
.027\end{array}$ & $\begin{array}{l}.066 \\
.058 \\
.047\end{array}$ & $\begin{array}{l}.043 \\
.039 \\
.034\end{array}$ \\
\hline $\begin{array}{l}11 \\
19 \\
22 \\
33\end{array}$ & Cut-in & & $\begin{array}{l}.066 \\
.048 \\
.044 \\
.037\end{array}$ & $\begin{array}{l}.075 \\
.054 \\
.049 \\
.041\end{array}$ & $\begin{array}{l}.070 \\
.05() \\
.046 \\
.038\end{array}$ \\
\hline
\end{tabular}




\subsubsection{Ceilings}

Ceiling insulation values were derived using the standard heat loss method described in the SGC Reference Manual (Baylon \& Heller, 1988) and associated spreadsheet, which were developed for site-built homes. While the spreadsheet was used to get an approximate value, some adjustments were necessary to account for the actual procedures used in the construction of manufactured homes.

There are two features of ceiling construction that are unique to manufactured homes. First, the absolute height of the structure is limited by the height of bridges and overpasses on the road systems which are used to transport the home to the building site. Thus, the slope of the roof and the amount of space between the truss cords is limited. Second, the trusses themselves are standardized and built largely to the same specifications used by all manufacturers.

The method by which insulation is installed varies from plant to plant. Two of the plants used blow-in insulation to fill the attic space. The SGC reference manual and spreadsheet was used to calculate U-factors for blown-in insulation since this method produces a fairly uniform insulation blanket which covers the truss cords as well as the area between the trusses. The remaining two-thirds of the homes in the sample, however, used fiberglass batts. This technique leaves an uninsulated slot over the trusses, thereby increasing the amount of ceiling area which has no insulation other than framing and wallboard. In addition, the batts must be placed to allow 1 inch of clearance for ventilation. One manufacturer achieved this by using a cardboard baffle, which compresses the batts at the edges below the roof sheathing. We corrected the ceiling $U$-factor to account for this compression. The other manufacturers ensured adequate ventilation by placing the batts in a stepped configuration (like stair steps). This meant an even larger correction must be made to account for the relatively large area of the attic where insulation is a fraction of the nominal total. Because of the dimensions of the truss in vaulted ceilings, there is less space available for the batts and the impact of staggering the batts on the overall ceiling U-factor is increased. These two ceiling insulation strategies are illustrated in Figures 3.2 and 3.3.

Table 3.2 shows the $U$-factor corrections made for flat and vaulted ceilings. These are compared to the values in the SGC specifications to illustrate the level of corrections that were necessary. Overall, these corrections amounted to a $10 \%$ to $15 \%$ increase in the amount of heat loss predicted by the SGC specifications. 

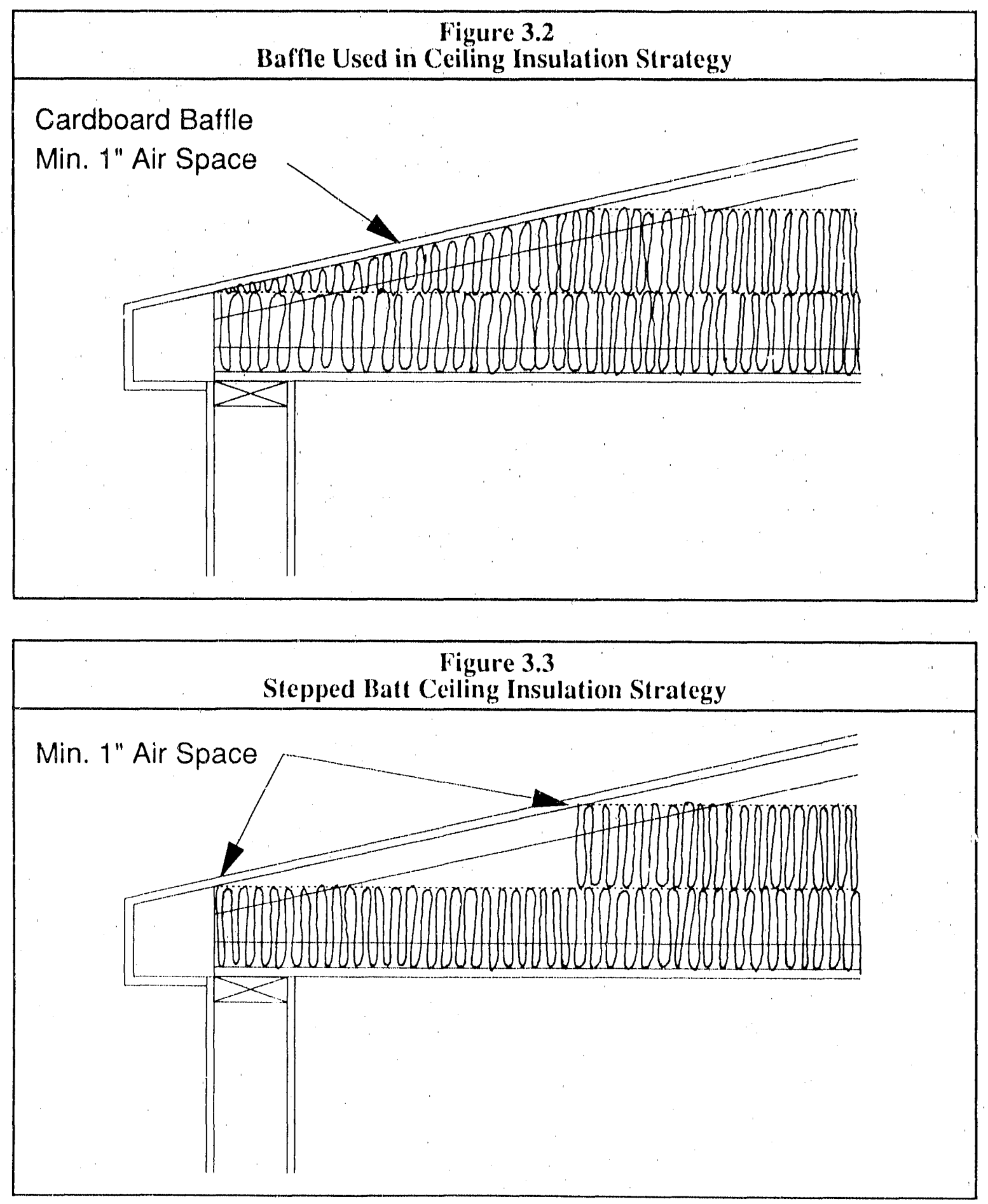


\begin{tabular}{|c|c|c|}
\hline \multicolumn{3}{|c|}{$\begin{array}{c}\text { Table } 3.2 \\
\text { Ceiling Heat Loss Rates }\end{array}$} \\
\hline \multicolumn{3}{|c|}{$\begin{array}{c}\text { Flat Ceiling } \\
\text { Standard Framing }\end{array}$} \\
\hline Nominal-R & $\begin{array}{c}\text { SGC } \\
\text { U-factor }\end{array}$ & $\begin{array}{l}\text { Revised } \\
\text { U-factor }\end{array}$ \\
\hline $\begin{array}{c}19 \\
22 \\
25 \\
30 \\
33 \\
38 \\
45 \\
49 \\
\text { Blow-in } 49\end{array}$ & $\begin{array}{l}.053 \\
.047 \\
.042 \\
.037 \\
.035 \\
.032 \\
.029 \\
.027 \\
.027\end{array}$ & $\begin{array}{l}.055 \\
.051 \\
.050 \\
.043 \\
.042^{*} \\
.040 * * \\
.038^{* * *} \\
.036^{* * *} \\
.029^{*}\end{array}$ \\
\hline \multicolumn{3}{|c|}{$\begin{array}{l}\text { * First } 2 \text { R-11 batts partially compressed, 3rd stacked } \\
* * \text { First R-19 batt partially compressed, } 2 \text { nd stacked } \\
* * * \text { First } 2 \text { batts crushed; last } 2 \text { batts stacked together } \\
\end{array}$} \\
\hline \multicolumn{3}{|c|}{$\begin{array}{ll}\text { Vaulted Ceiling } \\
\end{array}$} \\
\hline Nominal-R & $\begin{array}{c}\text { SGC } \\
\text { U-factor }\end{array}$ & $\begin{array}{r}\text { Revised } \\
\text { U-factor } \\
\end{array}$ \\
\hline $\begin{array}{c}19 \\
22 \\
25 \\
30 \\
33 \\
38 \\
\text { Blow-in } 38\end{array}$ & $\begin{array}{l}.054 \\
.048 \\
.044 \\
.039 \\
.037 \\
.035 \\
.031\end{array}$ & $\begin{array}{l}.055 \\
.052 \\
.051 \\
.044 \\
.043^{*} \\
.041^{* *} \\
.035\end{array}$ \\
\hline $\begin{array}{l}\text { * First } 2 \mathrm{R}-11 \text { ba } \\
\text { ** First R-19 bat }\end{array}$ & $\begin{array}{l}\text { ompress } \\
\text {, second }\end{array}$ & \\
\hline
\end{tabular}




\subsubsection{Heat Pumps and Duct Systems}

The RCDP program permitted the inclusion of heat pumps using an energy budget compliance approach. Only 32 of the homes in the sample used this approach.

Heat pumps were expected to have a minimum Heating System Performance Factor (HSPF) of 6.75. The heat pumps were manufactured by the Coleman Corporation and, for the most part, had performance ratings acceptable to the SGC prograin.

A modified version of the SUNDAY program was used to evaluate heat pump performance. We did not evaluate heat pump cooling energy use although in some of the climates where the heat pump was installed, a substantial cooling load might be expected, depending on occupant behavior.

We used the same program to simulate the duct system. The effect of the duct system and air distribution system were factored into a determination of heating system efficiency for homes with heat pumps and those with electric resistance furnaces. Duct losses were accounted for in two different ways:

1) Duct losses which resulted from uninsulated ducts located between the belly blanket and the floor insulation or from air leaks through the floor were used to correct and reduce floor insulation U-factors.

2) Duct losses due to infiltration were considered as a reduction in furnace efficiency and not in envelope performance. The heating systems in the manufactured homes consists of two continuous ducts tied together by a cross-over duct. The return side of the furnace is located in the utility room at one end of one side of the building. As a result, substantial differential pressure can be expected across the home, resulting in induced infiltration and air leakage from the warm supply duct to the outside.

The simulation procedures used to correct for heating system performance are explained in more detail in Section 4 of this report.

\subsection{Overall Building Heat Loss Rate}

Except for windows, the component heat loss rates derived from our analysis were higher than those calculated in the WATTSUN runs. Because of these differences, the overall building heat loss rate increased when compared with those from the WATTSUN runs. Since the results of the WATTSUN runs were never entered into the database, only a visual comparison was possible. A cursory review revealed an average $10 \%$ increase in overall heat loss rate. Even though the adjustments made in the floor and ceiling heat loss estimates increased the overall heat loss rate considerably, this increase was balanced by reductions in window U-factors. We used the tested U-factors for windows in our calculations, while the values used in the submittals were those supplied by the manufacturers and were over-estimated in some cases.

We calculated overall heat loss rates for each RCDP home and a corresponding base case home. In all cases, the base case was modelled as including the same window, door, wall, ceiling and floor areas as specified in the RCDP homes. 
The Department of Housing and Urban Development (HUD) sets health, safety and energy efficiency standards for manufactured homes. The minimum insulation level is expressed as Uo (overall heat loss rate), which is determined by dividing the sum of the steady-state conductivities for all components (except infiltration) by the total building surface area. For the Pacific Northwest, HUD regulations mandate a Uo of $0.126 \mathrm{~B} T \mathrm{TU} / \mathrm{ft}^{2}-\mathrm{hr}-{ }^{\circ} \mathrm{F}$.

Table 3.3 summarizes the most common nominal component $R$-values for the base case and RCDP homes. As can be seen, the most common strategy for meeting the SGC specifications in buildings without heat pumps was to use a window with an R-value of about 2.3 (U-factor of (0.43-(0.45), an R-19) wall, an R-30 floor (belly blanket and cavity instilation combined) and an R-38 ceiling.

The individual manufacturers chose a variety of strategies to meet the SGC specifications but (with the exception of the heating system) there was little variation in results. Even with corrected floor and ceiling $U$-values, different packages of conservation measures resulted in similar heat loss rates. Three manufacturers used heat pumps for heating equipment and these homes required less insulation to meet the SGC specifications. Nevertheless, these manufacturers also upgraded the insulation in the homes they built (although only one of them upgraded the windows).

\begin{tabular}{|c|c|c|c|c|c|c|c|c|c|}
\hline \multicolumn{10}{|c|}{$\begin{array}{c}\text { Table } 3.3 \\
\text { Most Frequent Conservation Measures } \\
\text { By Manufacturer } \\
\text { (R-Values) }\end{array}$} \\
\hline \multirow[b]{2}{*}{ Manufacturer } & \multicolumn{2}{|c|}{ Window } & \multicolumn{2}{|l|}{ Wall } & \multicolumn{2}{|l|}{ Floor } & \multicolumn{2}{|c|}{ Ceiling } & \multirow{2}{*}{$\begin{array}{l}\text { RCDP } \\
\text { Heating } \\
\text { System* }\end{array}$} \\
\hline & Base & RCDP & Base & $\mathrm{RCDP}$ & Base & $\mathrm{RCDP}$ & Base & RCDP & \\
\hline 1 & 1.33 & 1.33 & 11 & 19 & 11 & 22 & 21 & 38 & HP \\
\hline 2 & 1.33 & 2.22 & 11 & 19 & 11 & 3) & 19 & 38 & EF \\
\hline 3 & 1.33 & 2.08 & 11 & 19 & 11 & 33 & 14 & 38 & $\mathrm{EF}$ \\
\hline 4 & 1.33 & 2.32 & 11 & 19 & 7 & 22 & 14 & 33 & $\mathrm{HP}$ \\
\hline 5 & 1.33 & 1.33 & 11 & 19 & 7 & 30 & 14 & 33 & HP \\
\hline 6 & 1.33 & 2.32 & 11 & 19 & 11 & 36 & 14 & 33 & $\mathrm{EF}$ \\
\hline 7 & 1.33 & 2.08 & 11 & 22 & 7 & 33 & 19 & 49 & EF \\
\hline 8 & 1.33 & 2.22 & 11 & 22 & 11 & 44 & 14 & 38 & $\mathrm{EF}$ \\
\hline
\end{tabular}




\subsubsection{SGC Compliance}

Manufacturers used one of two paths for compliance with the SGC specifications: thermal performance and energy budget (heat pumps only). Most of the RCDP manufactured homes $(79 \%)$ used the thermal performance standards.

Thrmal Performance Compliance: The thermal performance path requires the calculation of a reference heat loss rate using the values specified in Table 3.4. A reference heat loss uses assumed values for floor, wall and ceiling areas and assumes u window area equal to $15 \%$ of the heated floor area.

\begin{tabular}{|l|c|c|c|c|c|c|}
\hline \multicolumn{7}{|c|}{$\begin{array}{c}\text { Component H.4 } \\
\text { by Climate Zone }\end{array}$} \\
\hline Component & \multicolumn{2}{|c|}{ Zone 1 } & \multicolumn{2}{c|}{ Zone 2 } & \multicolumn{2}{c|}{ Zone 3 } \\
\hline & U-factor & R-value & U-factor & R-value & U-factor & R-value \\
\hline Wall & .057 & 19 & .043 & 24 & .040 & 26 \\
\hline Floors & .029 & .33 & .029 & 33 & .029 & 33 \\
\hline Windows & .39 & 2.32 & .39 & 2.32 & .39 & 2.32 \\
\hline Doors & .19 & 5.2 & .19 & 5.2 & .19 & 5.2 \\
\hline Ceilings & .032 & .38 & .032 & 38 & .021 & 49 \\
\hline
\end{tabular}

Energy Budget Compliance: The energy budget path uses the reference heat loss values as inputs to a WATTSUN simulation which predicts the heating energy required by the proposed home in the climate where it is to be located. The proposed home is then modelled using the WATTSUN program and including a heat pump. The heat pump produces more heat per $k W h$ of input energy and thus offsets the heating requirement. As a result, the manufacture can produce a home which requires less insulation or has additional glazing than a similar home with electric resistance heat.

The insulation packages used in the RCDP program generally did not meet the nominal U-factors used to compute the reference building heat loss rate. To compensate, the manufacturers reduced the amount of window area below the $1.5 \%$ anticipated in the SGC specifications. This gave them more flexibility with the component values used to meet the SGC specifications. Table 3.5 summarizes the window areas used in the RCDP manufactured homes.

\begin{tabular}{|c|c|c|c|c|}
\hline \multicolumn{5}{|c|}{ Table 3.5 } \\
\hline \multirow{2}{*}{$\begin{array}{c}\text { Climate } \\
\text { Zone }\end{array}$} & \multicolumn{2}{|c|}{ Electric Furnace Window Areas } \\
\cline { 2 - 5 } & Area & \% of Floor Area & Area & \% of Floor Area \\
\hline 1 & 145 & 10.2 & 178 & 11.0 \\
\hline 2 & 153 & 9.8 & 214 & 12.8 \\
\hline 3 & 161 & 9.6 & -- & - \\
\hline
\end{tabular}


A review of the WATTSUN compliance runs indicated that most m nufacturers vere within $1 \%$ of the reference heat loss when using the thermal performance path. As a result, the homes complying under this path did not meet the compliance standards when the corrected U-factors for ceilings and floors were used.

The homes complying using the energy budget approach generally exceeded the standards by more than $10 \%$ and thus would have complied without major changes in reference heat loss values.

\subsubsection{Heat Loss Rates}

These RCDP homes achieved substantial reductions in heat loss rate over the heat loss rates estimated for the same hones using the standard (base) insulation packages provided by the manufiacturers.

Table 3.6 summarizes the reduction in overall heat loss rate and illustrates the impact of the heat pump compliance path on the conservation program. Homes which used conventional electric furnaces show a $35 \%$ reduction in total $U A$, while homes which use heat pumps have a $2.5 \%$ reduction. All R-values and $U$-factors ased in these calculations are steady-state and do not take into account furmace efficiency, duct losses or corrections to the floor insulation due to duct placement.

The Uo value is equal to the UA (minus the infiltration heat loss) divided by the surface area of the house and is used to compensate for differences in average house size among manufacturers and thus facilitate comparison of thermal performance.

\begin{tabular}{|c|c|c|c|c|c|c|c|c|c|}
\hline \multicolumn{10}{|c|}{$\begin{array}{c}\text { Table } 3.6 \\
\text { Average Heat Loss Rates By Manufacturer } \\
\text { (Btu/hr) }\end{array}$} \\
\hline \multirow[b]{2}{*}{$\begin{array}{l}\text { Manu- } \\
\text { facturer }\end{array}$} & \multirow[b]{2}{*}{$\begin{array}{c}\text { Avg } \\
\text { Area }\end{array}$} & \multicolumn{2}{|c|}{ Base } & \multicolumn{3}{|c|}{ RCDP with ER } & \multicolumn{3}{|c|}{ RCDP with HP } \\
\hline & & UA & Uo & UA & $U_{0}$ & $\begin{array}{l}\% \\
\text { UA Re- } \\
\text { duction }\end{array}$ & UA & Uo & $\begin{array}{l}\% \\
\text { UA Re- } \\
\text { duction }\end{array}$ \\
\hline 1 & 1742 & 588 & .102 & -- & - & $\ldots$ & 482 & .080 & 19.1 \\
\hline 2 & 1550 & 522 & .101 & 341 & .061 & $33 .()$ & 415 & .074 & 24.3 \\
\hline 3 & 1519 & $5(1) 3$ & .098 & 349 & .062 & 30.8 & -- & -- & $\cdots$ \\
\hline 4 & 1387 & 482 & .108 & 324 & .061 & 35.1 & 308 & .068 & 33.7 \\
\hline 5 & 1559 & 563 & .110 & 306 & .060 & 38.2 & 4.53 & .080 & 24.3 \\
\hline 6 & 1268 & 451 & .105 & 266 & .055 & 41.2 & -- & -- & $\cdots$ \\
\hline 7 & 16.32 & 549) & .107 & 363 & .063 & 33.8 & 464 & .070 & 33.7 \\
\hline 8 & 1478 & 519 & $.1(03$ & 319 & (0).57 & 38.6 & -. & -- & -. \\
\hline ALL & 1576 & 527 & .104 & 327 & .059 & 35.8 & 4.36 & .077 & 25.2 \\
\hline
\end{tabular}


The impact of the SGC specifications was similar across manufacturers. The only significant difference between the base case and RCDP homes occurs for homes with heat pumps. UA changes were about $10 \%$ less for heal pump homes. All other differences were not significant, despite the fact that a more stringent code was enforced in climate zones 2 and 3.

The differences between manufacturers in overall heat loss rates can be explained almost entirely by the size of the homes. Manufacturer \#6, for example, had the smallest homes in the sample and as a result lower heat loss rates compared to the other manufacturers. Furthermore, this manufacturer had a $12 \%$ lower matio between glass and floor area than the overall average.

Since the SGC compliance reculirements were more stringent for Zone 2 and Zone 3 climates, a summary of UA by climate should reveal a reduced UA. This did not occur as shown in Table 3.7.

\begin{tabular}{|c|c|c|c|c|c|c|c|c|}
\hline \multicolumn{9}{|c|}{$\begin{array}{c}\text { Table } 3.7 \\
\text { Average Heat Loss Rates } \\
\text { by Climate Zone }\end{array}$} \\
\hline & \multicolumn{2}{|c|}{ Base } & \multicolumn{3}{|c|}{ RCDP with ER } & \multicolumn{3}{|c|}{ RCDP with IIP } \\
\hline Zone & UA & Uo & UA & Uo & $\begin{array}{l}\% \% \\
\text { UA Re- } \\
\text { duction }\end{array}$ & UA & Uo & $\begin{array}{l}\% \\
\text { UA Re- } \\
\text { duction }\end{array}$ \\
\hline 1 & 517 & .105 & 319 &.$(1) 60$ & 36.2 & 43() & .077 & 26.1 \\
\hline 2 & 537 & .102 & 3.39 & .059 & 35.5 & 453 & .078 & 22.6 \\
\hline 3 & 556 & .10() & 366 & .050 & 34.8 & $\cdots$ & -. & -- \\
\hline
\end{tabular}

While the total heat loss rate increases with climate zone, the Uo does not. The slight downward trend is not statistically significant although it is consistent with values which might be expected from the SGC specifications.

To examine the deteminants of heat loss rates among manufacturers, we conducted a regression analysis using UA as a dependent variable. When overall floor area was used as a predictor of the UA for the RCDP homes (controlling for heating system), the model explained $92 \%$ of the variance. The addition of other independent variables (manufacturer and climate zone) did not have a significant impact on the regression or the overall $R^{2}$. When the $U_{0}$ is used as a dependent variable, the combination of climate zone and manufactures explains about $34 \%$ of the variance in Uo. Climate zone by itself, however, does not have a significant relationship with Uo or UA.

Figure 3.3 shows the range of home sizes by manufacturer. The variation in sizes remains significant throughout the thermal analysis as the major determinant of overall performance. 
Figure 3.3

Ilome Size by Manufacturer

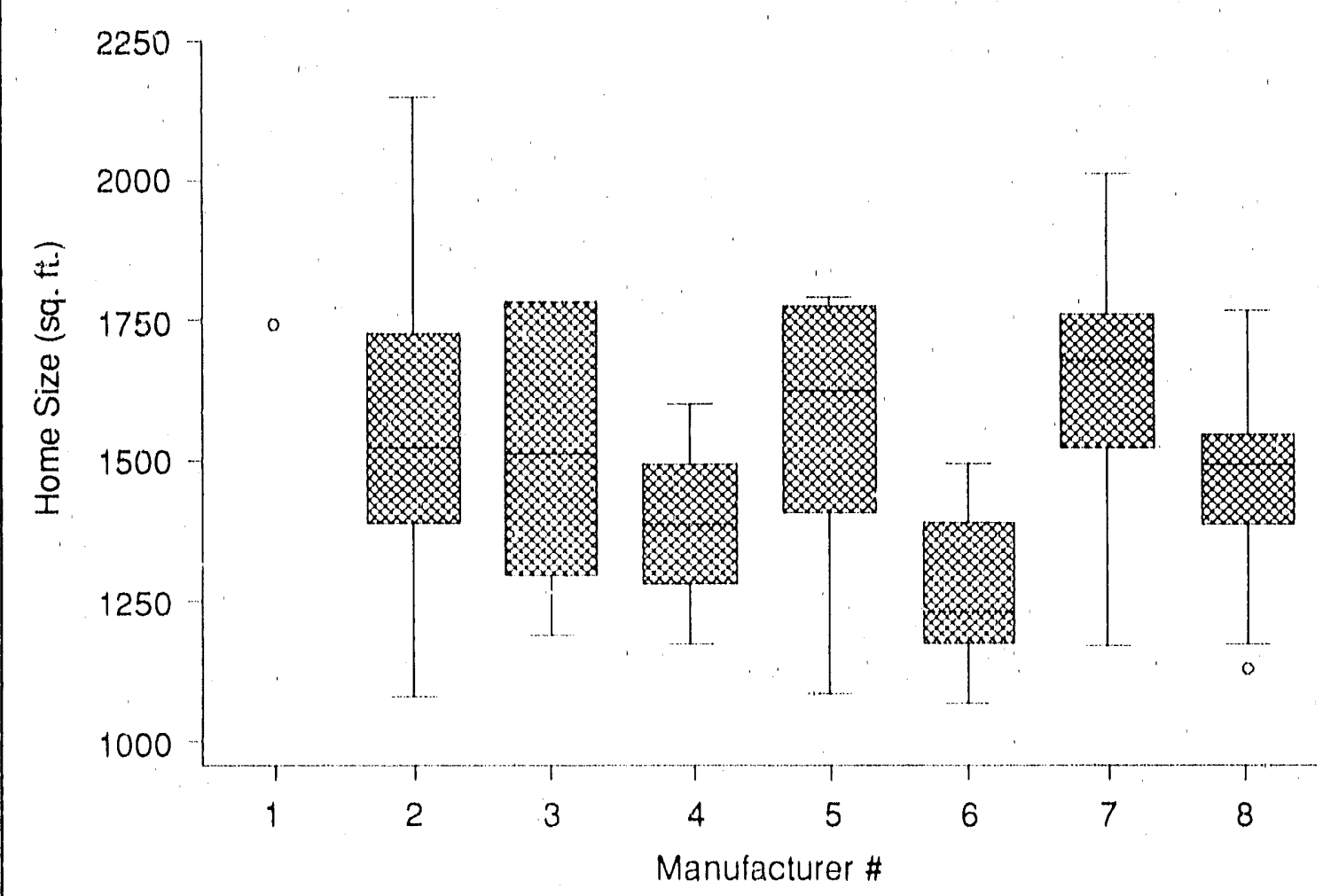




\section{Thermal Performance: Energy Savings}

The thermal performance of the RCDP homes was estimated by running a thermal simulation of each home as built and on the same home as it would have been built without the SGC specifications (base case). To define the base case home, we used the dimensions of the home as built, the components provided by the manufacturers in their basic model homes and the insulation levels specified by the manufacturers to comply with Housing and Urban Development (HUD) regulations for manufactured homes. Although consumers may request changes which affect the energy efficiency of the homes they purchase, we did not use consumer preference as a basis for our savings estimates in this report since it is not standardized or predictable.

\subsection{Simulation Assumptions}

Several assumptions are necessary to produce a thermal simulation. These assumptions are all linked to occupant behavior or field performance and not to building heat loss rate and heating system type:

The thermal simulation program requires inputs of thermal mass, thermostat setpoints, internal gains and infiltration rates. We used the same values which were used in the WATTSUN program. These included a thermostat setpoint of $65^{\circ} \mathrm{F}$, a thermal mass assuming light-frame construction, $3,()()() \mathrm{Btu} / \mathrm{hr}$ of internal gains, and an infiltration rate of ().35 ACH.

In real life, these variables are affected by the occupant's life style. By standardizing them to particular values, the underlying impact of the SGC specifications on performance can be determined. However, since particular occupants might interact with their homes in different ways, the relationship between the simulation results and the actual heating requirements may be quite poor. In later phases of this study, data collected during field tests will be used to refine the simulation results.

\subsection{Weather Sites}

The SUNDAY simulation uses weather data from 33 sites throughout the Northwest region to simulate the weather in each locality'. 'These sites correspond to the weather stations used by the WATTSUN program.

A weather site was assigned to each RCDP home based on the address of the final location of the home. This weather site was allocated based on the geographic and climatic proximity of the site to one of the SUNDAY sites. Table 4.1 lists the 16 weather sites used in the analysis and the number of homes assigned to each of these sites.

In addition, we identified the climate zone of each home based on the degree days at those sites. Sites with less than $6,()(0)$ degree days were considered to be in Climate Zone 1 , sites with $6,()(0)$ 10 $8,()(0)$ degree days were in Zone 2 , and sites with over $8,(0)()$ degree days were assigned to Zone 3. These assignments varied some what from the climate zones used in the WATTSUN simulations. For example, the Republic site in northeast Washington was considered Zone 2 for the WA'TSUN run. It is, in fact, a Zone 3 site by our definition. Similarly, Yakima was defined as a Zone 1 site but was in fact a Zone 2 site. As a resull, several homes assigned to these weather sites were reclassified lo ensure that the climate zone variable could be used in the performance annlysis. In all cases, we summarized the data using our zone designations. 


\begin{tabular}{|c|c|c|c|}
\hline \multicolumn{4}{|c|}{$\begin{array}{c}\text { Tabic } 4.1 \\
\text { Weather Sites } \\
\text { (Number of Ilomes) }\end{array}$} \\
\hline $\begin{array}{l}\text { SUNDAY } \\
\text { Weather } \\
\text { Station }\end{array}$ & $\begin{array}{c}\text { Climate } \\
\text { Zone } \\
1\end{array}$ & $\begin{array}{c}\text { Climate } \\
\text { Zone } \\
2\end{array}$ & $\begin{array}{c}\text { Climate } \\
\text { Zone } \\
\mathbf{3}\end{array}$ \\
\hline A'storia, OR & 4 & & \\
\hline Bellinghum, WA & 6 & & \\
\hline Kalispell, MT & & & 1 \\
\hline Lewiston, ID & 1 & & \\
\hline Newport, OR & 2 & & \\
\hline Olympia, WA & 20 & & \\
\hline Pendleton, OR & 1 & & \\
\hline Portland, OR & 5 & & \\
\hline Redmond, OR & & 20) & \\
\hline Republic, WA & & & 4 \\
\hline Richland, WA & 2 & & \\
\hline Salem, OR & 2 & & \\
\hline Seattle, WA & 35 & & \\
\hline Spokane, WA & & 14 & \\
\hline Whidbey Island, WA & 6 & & \\
\hline Yakima, WA & & 25 & \\
\hline TOTAL & 84 & 59 & 5 \\
\hline
\end{tabular}

\subsection{Heating Systems}

The SUNDAY program has been enhanced to include a direct simulation of ducts and heating systems, especially heat pumps. These modifications were developed using the work of Palmiter and Kennedy (1983), Robison (1988), Modera (1988) and Kennedy (1990). The enhanced program takes into account the principal factors of duct performance: duct leakage from the supply and return ducts into the buffer space, heat conductivity from the supply ducts into the buffer space, and induced infiluation brought on by differential pressure across the envelope as a result of supply air being clelivered at a substantial distance from the furnace. 
The main duct losses associated with the manufactured home floor system are caused by conductivity and leakage in the buffer space between the belly blanket and the floor structure. These effects reduce the nominal $R$-value of floor insulation, and hence, increase the U-factors as can be seen in Table 3.1. The impact of the duct losses on the total floor is much less when there is no insulation between the duct and the floor, as is the case in the base case insulation strategies. We elected to account for the extra losses associated with the supply duct system as a reduction in the effective $U$-factor of the floor, since the same insulation could be installed within the floor system in such a way as to minimize this effect. The thermal losses associated with induced infiltration were translated into reduced furnace efficiency, although some proportion of the supply duct losses could be counted as reduced furnace efficiency.

We used the actual capacity of the heating system and the specifications for the floor to determine the mass flows and cycle times of the air handler operation. The standard ASHRAE bin method was used to determine the duty cycle of the furnace and the temperature of the duct system. A full discussion of this simulation technique is contained in Kennedy (1990).

One manufacturer insulated the full length of all the ducts in the floor system. As a result this manufacturer was not as heavily penalized in performance of floor systems as the others, who used mostly uninsulated ducts. This is significant since this manufacturer also produced approximately $60 \%$ of all the RCDP homes with heat pumps, thus enhancing the performance of the heat pumps and the energy savings associated with them.

Another manufacturer used a longitudinal floor joist system so that the joists ran parallel to the underlying I-beam. This allowed the ducts to be placed inside the floor cavity so they were not insulated from the home. In this case, the ducts performed much better than in cases where the ducts were below the floor joist insulation.

In the remaining cases, the ducts were located below the floor structure but above the belly blanket and thus duct losses were contained within this buffer area.

We simulated both types of heating systems used in the manufactured homes. For electric resistance furnaces, we assumed that the furnaces themselves were $100 \%$ efficient and that all inefficiencies resulted from duct losses and induced infiltration.

For this analysis, an adjusted HSPF was calculated across the entire range of thermal loads. We simulated heat pumps using the specifications provided by the heat pump manufacturer, including HSPF and rated Coefficient of Performance (COP). These values are determined by stardard tests throughout the industry (ARI, 1989). Since heat pump performance varies substantially with outdoor temperature and load, each home was simulated with the heat pump to get an estimate of performance. The heat pump performance was calculated using the bin method for each point over the range of temperatures contained in the SUNDAY weather file. The adjusted HSPF differed appreciably from the published HSPF.

Nevertheless, since the simulation uses the actual temperatures for the site on which the home is located, this estimate of performance should be much more accurate than the general HSPF published by the manufacturer. In fact, since the standard rating assumes a climate harsher than most of the climates in Washington and Oregon, the performance of the heat pump is enhanced by using this simulation. 
The difficulty here is that the simulation assumes that the heat pump is operating properly with minimum setbacks and duty cycles appropriate to the outside temperature and a fixed thermostat setpoint. If the occupant insists on large night setbacks--which force the heat pump into a substantial warm-up cycle in the morning--the heat pump will operate the resistance coils and the system will function very much like an electric resistance huater. This mode of operation could account for a substantial portion of the heat load of the building during the heating season. In these circumstances, the apparent ifficiency of the system would be better described as an electric resistance furnace than as a heat pump. In the absence of any direct evidence about how these buildings are operated, we assumed that the heat pump was operated appropriately to ensure its maximum efficiency. When field data have been collected and reviewed, this assumption will be evaluated.

\subsection{Results}

Table 4.2 summarizes the results of the thermal simulation estimates. These runs use the same standard assumptions; the only variables are UA, weather site and heating system type.

The variation between manufacturers remains minimal except insofar as some manufacturers produced smaller or larger homes than average. Variation by climate zone is a function of the colder temperatures in Zones 2 and 3--larger energy requirements result in larger potential savings, given the same UA. As we have already seen, the variation in UA between climate zones is not significant. In this evaluation of energy savings, climate zone is a good predictor, although savings are largely due to changes in heat loss and the use of heat pumps.

The SUNDAY evaluation confirmed the pattern seen in the UA-only analysis. The homes of Manufacturer \#6 were more energy-efficient than the average, largely because of the reduced glass area, and the homes of Manufacturer \#5 were more efficient than the average, largely because of the insulated ducts and this more effective floor insulation.

Savings from duct insulation and the resulting improved floor insulation performance are estimated at $10(0) \mathrm{kWh} /$ year in the RCDP homes, as shown in Appendix B. This represents an increase in savings of $10-20 \%$ in homes without heat pumps.

\begin{tabular}{|c|r|r|r|r|r|r|r|r|r|r|r|r|}
\hline \multicolumn{10}{|c|}{ Table 4.2 } \\
\multicolumn{8}{|c|}{ Simulated Heating Energy Performance and Savings } \\
(Average Values)
\end{tabular}

The overall savings for the RCDP homes is approximately $51 \%$ for both heating system types. Savings of $44 \%$ on average were achieved for the systems using forced air furnaces and $71 \%$ for heal pumps. 
While various manufacturers used different combinations of components to comply with the SGC specifications, the net effect on building performance was very similar across

manufacturers. To illustrate this point, we used a regression and a 2 -way analysis of variance to analyze the relationship between overall heating performance, climate zone and floor area for homes with electric resistance furnaces. The results achieved an $\mathrm{R}$-square of 0.95 , indicating that less than $5 \%$ of the remaining variance in performance was not explained by climate zone and floor area. In the case of heat pumps, the relationship was not as strong, since the heat pump performance is partly a function of individual climates and variations in heat pump size were requested by the consumer. Nevertheless the R-square of this regression was 0.84 , suggesting that less than $16 \%$ of the variance could be explained by all other factors including heat pump sizing and performance. When the manufacturer is added as is variable to this model, the correlation does not improve.

Variations in performance and savings estimates among manufacturers were not statistically significant even after controlling for climate and floor area. Table 4.3 compares savings and building size by manufacturer.

\begin{tabular}{|c|c|c|c|c|}
\hline \multicolumn{5}{|c|}{ Table 4.3 } \\
Manufacturer & $\begin{array}{c}\text { Electric } \\
\text { Resistance } \\
(\mathbf{k W h})\end{array}$ & $\begin{array}{c}\text { Average } \\
\text { House } \\
\text { Size } \\
\left(\mathbf{f t}^{2}\right)\end{array}$ & $\begin{array}{c}\text { Heat Pump } \\
(\mathbf{k W h})\end{array}$ & $\begin{array}{c}\text { Average } \\
\text { House } \\
\text { Size } \\
\left(\mathbf{f t}^{2}\right)\end{array}$ \\
\hline $\mathbf{1}$ & & & 11036 & 1742 \\
\hline $\mathbf{2}$ & 6546 & 1547 & 10990 & 1567 \\
\hline $\mathbf{3}$ & 5519 & 1519 & & \\
\hline $\mathbf{4}$ & 6021 & 1493 & 9100 & 1280 \\
\hline $\mathbf{5}$ & 7424 & 1390 & $11400)$ & 1648 \\
\hline $\mathbf{6}$ & 6437 & 1268 & & \\
\hline $\mathbf{7}$ & 8273 & 1594 & 13414 & 1884 \\
\hline $\mathbf{8}$ & 7997 & 1479 & & \\
\hline
\end{tabular}

Taken as a whole, the thermal performance of RCDP homes in this project represents a significant improvement over the base case manufactured homes. While the specifications need some refinement, the initial engineering review of these homes suggests savings in electricity used for heating in excess of $50 \%$. This is largely due to the base case R-value specifications for these products, which are dramatically below the standards set by either the Washington or Oregon state energy codes and below any current practice in site-built homes. However, once the SGC specifications are applied to these homes, performance at the same level as, or better than, site-built homes with similar specifications might be anticipated. 


\section{Cost-Effectiveness}

To establish the cost-effectiveness of the SGC specifications for manufactured homes, we used a two-part process. First, we applied a levelized cost factor to the present value of the entire package over the life of each home to arrive at a cost-benefit ratio expressed in $\$ / \mathrm{kWh}$ saved. Then, by estimating the cost-effectiveness of each potential conservation measure when applied to a prototypical manufactured home in each climate zone, we identified optimum packages of conservation measures.

The cost-benefit analysis is based on data from 149 of the 150 RCDP manufactured homes; one home was eliminated from the sample due to an unusual wall-framing technicque.

\subsection{Assumptions and Life Cycle Cost Adjustments}

BPA (James, 199()) provided us with standard assumptions to determine the

cost-effectiveness of conservation measures applied to manufactured homes. These are:

1) a life expectancy of 45 years for all envelope measures, except windows

2) a life expectancy of 30 years for windows,

3) a life expectancy of 15 years for heat pumps,

4) an annual real discount rate of $3 \%$,

5) $52 \mathrm{mills} / \mathrm{kWh}$ avoided cost of electricity.

To ensure that all conservation measures last for the full economic life of the manufactured home, we assumed that the entire incremental heat pump cost is incurred (outdoor unit and indoor coil) at 15 years and again at 3() years, at the full cost discounted to present value. No additional maintenance costs were included. While this is probably a simplification, the replacement cost could be considered the cost of maintaining a heat pump in working order over the life of the building. We assumed that the windows will be replaced at the same incremental cost as the initial windows and thus all window prices were adjusted to account for replacement at the end of 30 years.

\subsection{Cost-Benefit Analysis}

\subsubsection{Package Costs}

For the first step in cost-benefit analysis, we computed the price of the SGC package for each home built under RCDP.

Table 5.1 summarizes the reported and standardized wholesale costs and the standardized and present value retail costs of the SGC package. The reported wholesale costs were those costs provided by the manufacturers and summarized in the cost analysis repont (Baylon, Lubliner \& Davis, 199()). These costs were then standardized to compensate for variations in the wholesale pricing policies of different manufacturers by computing a median mark-up for each component and multiplying this by the cost of materials to produce a standardized wholesale cost. The standardized wholesale component costs were summed to get a standardized wholesale package cost. The standardized retail cost is the standardized wholesale cost multiplied by a standardized dealer mark-up. The present value retail cost reflects the adjustment in costs for replacing heat pumps and windows during the life of the home. 


\begin{tabular}{|c|c|c|c|c|c|c|c|c|}
\hline \multicolumn{9}{|c|}{$\begin{array}{c}\text { Table } 5.1 \\
\text { SGC Package Prices } \\
(\$ / \text { home })\end{array}$} \\
\hline \multirow[t]{2}{*}{ Manufacturer } & \multicolumn{2}{|c|}{$\begin{array}{c}\text { Manufacturers } \\
\text { Wholesale }\end{array}$} & \multicolumn{2}{|c|}{$\begin{array}{c}\text { Standardized } \\
\text { Wholesale }\end{array}$} & \multicolumn{2}{|c|}{$\begin{array}{l}\text { Standardized } \\
\text { Retail }\end{array}$} & \multicolumn{2}{|c|}{$\begin{array}{l}\text { Present } \\
\text { Value } \\
\text { Retail }\end{array}$} \\
\hline & Elec & IIP & Elec & IIP & Elec & IIP & Elec & HP \\
\hline 1 & & 4291 & & 4702 & & 5132 & & 8578 \\
\hline 2 & 3096 & 4720 & 2954 & 5512 & 3841 & 6185 & 4344 & 10044 \\
\hline 3 & 2343 & & 3126 & & 4064 & & 4777 & \\
\hline 4 & 2617 & 4747 & 2073 & 5248 & 2694 & 5733 & 2861 & 9241 \\
\hline 5 & 3217 & 5438 & 25.32 & 5066 & 3292 & 5432 & 3482 & 8697 \\
\hline 6 & 2431 & & 2071 & & 2693 & & 2869 & \\
\hline 7 & 3518 & 6.469 & 3839 & 7907 & 4991 & 9623 & 5797 & 14461 \\
\hline 8 & 3401 & & 2805 & & 3646 & & 4114 & \\
\hline ALL & 3088 & 5244 & 2864 & 5355 & 3724 & 5892 & 4205 & 9425 \\
\hline
\end{tabular}

Once heating systems are included, the variance in price is largely explained by the size of the home and window area. Climate zone is also significant in determining the final price of the packages. This suggests that manufacturers did attempt to respond to the $\mathrm{SGC}$ requirements with higher nominal insulation values, but the corrections made to the floor and ceiling $U$-factors mask these differences.

\subsubsection{Cost-Benefit}

SGC package savings were analyzed in Section 4 of this report. The savings are computed as a difference between energy used in the RCDP and base case home. The savings estimates are largely a function of U-factor, climate zone and heating system types.

Table 5.2 summarizes the results of the cost analysis and the savings analysis and derives a cost per kWh salved.

There is a large difference between buildings with heat pump systems and buildings with conventional electric fumaces. This difference is consistent across all zones, although we have no cases where heal pumps were used in Zone 3. Furthermore, the cost of the heat pump drives up the cost of energy saved by almost $25 \%$ even though it results in a $60 \%$ increase in energy savings. The increalsed cost for heat pump packages reflects the relatively high life cycle cost associated with replacing the heat pump during the life of the home. 


\begin{tabular}{|c|c|c|c|c|c|c|}
\hline \multicolumn{7}{|c|}{$\begin{array}{c}\text { Table } 5.2 \\
\text { SGC Conservation Package Savings }\end{array}$} \\
\hline $\begin{array}{l}\text { Climate } \\
\text { Zone }\end{array}$ & $\begin{array}{l}\text { Heating } \\
\text { System } \\
\text { Type }\end{array}$ & $N$ & $\begin{array}{c}\text { Average } \\
\text { Anmual } \\
\text { kWh } \\
\text { Savings }\end{array}$ & $\begin{array}{l}\text { Average } \\
\text { Present } \\
\text { Value } \\
\text { Retail } \\
\text { Price (\$) }\end{array}$ & $\begin{array}{l}\mathrm{UA} / \mathrm{ft}^{2} \\
\text { (living } \\
\text { area) }\end{array}$ & $\begin{array}{l}\text { Levelized } \\
\text { Cost } \\
\text { of } \\
\text { Savings } \\
\text { (\$/kWh) }\end{array}$ \\
\hline \multirow[t]{2}{*}{1} & Elect & 60 & $6(021$ & 3851 & .223 & .)27 \\
\hline & HP & 24 & 10869 & 9327 & .267 & .036 \\
\hline \multirow[t]{2}{*}{2} & Elect & 51 & 7963 & 4552 & .218 & .025 \\
\hline & $\mathrm{HP}$ & 8 & 12473 & 9716 & .271 & .032 \\
\hline \multirow[t]{2}{*}{3} & Elect & 5 & $11000)$ & 4916 & .216 & .019 \\
\hline & $\mathrm{HP}$ & () &.- & $\ldots$ & $\ldots$ & $\ldots$ \\
\hline \multirow[t]{2}{*}{ ALL } & Elect & 116 & 6725 & 4205 & .221 & .026 \\
\hline & $\mathrm{HP}$ & 32 & 11270 & 9425 & .268 & .035 \\
\hline TOTAL & & 148 & 7707 & 5330 & .231 & .028 \\
\hline
\end{tabular}

Table 5.2 shows the UA per scuare foot of living space for each zone by heating system. This table illistrates the similarity in performance of homes in this sample across all climate zones. The average U-factor per scjuare foot in Climate Zone 3 is only $5 \%$ below the average in Climate Zone 1. As a result of this, conservation in Zone 3 is considerably more cost-effective, since the same measures applied in a colder climate offer a larger potential savings. This also indicates that more marginal measures would have been cost-effective in this climate zone since the packages that were used reduced the life cycle cost of conservation by almost $30 \%$ from the cost for Zone 1 . On average, the UA/ $\mathrm{ft}^{2}$ for these homes is about $10 \%$ above the SGC reference heat loss.

Taking the region as a whole, the levelized cost per $k$ Wh of saved energy is 28 mills. For packases with electric resistance furnaces, this average is 26 mills; for packages with heat pumps the average is 35 mills. These levelized costs are based on the standardized retail cost to the consumer, taking into account (where appropriate) the cost of replacing windows and heat pumps.

\subsubsection{Consumer Benefits}

Another way to look at the SGC package cost is to construct a consumer scenario in which the consumer borrows on a 2 () year note at $13 \%$ interest. Table 5.3 summarizes these results.

Financing the cost of the SGC package without the BPA subsidy results in a negative cash flow during the first year. With the subsidy, the first year cash flow is positive for electric resistance homes in all zones. Heat pumps only exhibit a positive cash flow in Zone 2. This suggests that the cost-effectiveness of the heat pump option is less attractive than the envelope measures, particularly in Climate Zone 1. 


\begin{tabular}{|c|l|r|r|}
\hline \multicolumn{5}{|c|}{$\begin{array}{c}\text { Table 5.3 } \\
\text { Consumer Cash Flow } \\
\text { SGC Packages } \\
\text { (Ycar One Averages) }\end{array}$} \\
\hline $\begin{array}{c}\text { Climate } \\
\text { Zone }\end{array}$ & \multicolumn{1}{|c|}{$\begin{array}{c}\text { Heating } \\
\text { System }\end{array}$} & $\begin{array}{c}\text { No } \\
\text { Incentive }\end{array}$ & $\begin{array}{c}\text { SGC } \\
\text { Incentive }\end{array}$ \\
\hline $\mathbf{1}$ & Electric & -207 & 78 \\
\hline & Heat Pump & -324 & -39 \\
\hline $\mathbf{2}$ & Electric & -195 & 161 \\
\hline & Heat Pump & -265 & 91 \\
\hline $\mathbf{3}$ & Electric & -101 & 326 \\
\hline & Heat Pump & -- & -- \\
\hline ALL & Electric & -197 & 125 \\
\hline & Heat Pump & -309 & -7 \\
\hline
\end{tabular}

The assumptions used to generate this table include a cash flow based on an annualized (levelized) payment on a $2(0$ year loan at $13 \%$ interest (consistent with the current rates offered by local financial institutions) and a regional average cost for electricity of 47 mills. Package costs include only the first cost of the individual measures and do nor take into account maintenance costs or tax benefits that might accrue from interest payments. With SGC subsidies, even without optimization of the cost-benefit ratio of the SGC package, the manufactured home buyer will see a positive cash flow despite a relatively short loan life and high interest rate.

\subsection{Optimum Conservation Packages}

In addition to evaluating the cost-effectiveness of the SGC packages as applied to the RCDP homes, we identified optimum conservation strategies for these homes using an optimization analysis. For all components but floors, this analysis included energy conservation measures that were used by manufacturers during the RCDP. These measures were assigned costs as determined by the standardized cost analysis and were assigned U-factors as discussed in Section 3 of this report.

\subsubsection{Optimization Assumptions}

Optimization is a cost-benefit analysis in which individual conservation measures are assessed separately to determine their contribution to the cost-effectiveness of an entire package. Optimum packages were developed using a cost ceiling of 52 mills for all measures. We used a SUNDAY-based optimization program similar to that developed for the conservation supply curve (Palmiter and Baylon, 1982) to calculate actual performance. The SUNDAY runs were conducted using a series of component upgrades applied to a base building. 
The base building is described in Table 5.4 and reflects the avernge size manufactured home from the database. To make the evaluation more realistic, we used specifications from a home in the database. The plans and construction for this prototype manufactured home are shown in Appendix A.

\begin{tabular}{|c|c|c|}
\hline \multicolumn{3}{|c|}{$\begin{array}{c}\text { Table } 5.4 \\
\text { Base Case Assumptions }\end{array}$} \\
\hline & $\begin{array}{c}\text { Area } \\
\left(\mathrm{Ni}^{2}\right)\end{array}$ & $\begin{array}{l}\text { Nominal Values } \\
\text { R-and U-Factors }\end{array}$ \\
\hline Windows & 150 & $\mathrm{U}=.75 \mathrm{Btu} / /^{\circ} \mathrm{F}-\mathrm{hr}$ \\
\hline Walls & 1056 & $\mathrm{R}-11$ (2x6 framing), $\mathrm{U}=.088$ \\
\hline Floors & 1493 & R-7 (Belly blanket only), $\mathrm{U}=.097$ \\
\hline Ceilings, Flat & 747 & $R-14, U=.066$ \\
\hline Ceilings, Vaulted* & 756 & $R-14, U=.066$ \\
\hline Doors & 4() & $\mathrm{U}=.19 \mathrm{Btu} /{ }^{\circ} \mathrm{F}-\mathrm{hr}$ \\
\hline Infiltration & $(11750)$ & $.35 \mathrm{ACH}$ \\
\hline Thermostat Setting & & $65^{\circ} \mathrm{F}$ \\
\hline Mass & & Light frame \\
\hline Internal Gains & & $3,000 \mathrm{Btu} / \mathrm{hr}$ \\
\hline Heating System & & Electric resistance furnace \\
\hline
\end{tabular}

The optimization procedure uses the SUNDAY program to predict the thermal performance of the base case building and then assess the impact of individual component upgrades. This is done by running the SUNDAY simulation on the base case building with the base assumptions, then adding each possible conservation option individually. Each run generates an estimate of the diminished heating energy requirements obtained with successive conservation measures.

Table 5.5 shows the levelized cost for each measure included in the basic package of options for optimization in each climate zone. 'To correctly determine the effect of mutually exclusive options, we did separate optimizations in the se cases. For example, conventional floor construction was optimized independently of non-conventional foor construction. Blown-in altic insulation was applied by only two manufacturers and indeed most manufacturers did not have the equipment aviilable for this technology. Thus, blow-in ceiling insulation was optimized separately from batt insulation. The heat pump was included in each optimization as one of the possible conservation measures. However, since many manufacturers chose the heal pump option as a marketing stralegy, we also did two optimization runs using the heat pump as the base case heating system. The levelized costs included in Table 5.5 are from runs in which heat pumps were not included. 
The optimization process moves ench option into the ophimization individually, It then selects the most costerfectlve option against the base calse. 'This option is entered as the first on the list and also lncluded again in the "revised" base case and the entire process is repeated until all the options have been added in the order of their cost-effectiveness. The individual conservation assessment of each option is based on the new UA (heat loss rate) and characteristics of the building after its addition. The suvings computed for each option are corrected for the non-linear relationship belween heat loss rale and overall performance, thus preventing double-counting.

All optimization runs were redone for each climate zone. Weather data from Seattle, Washington was used to characterize Climale Zone 1, Spokane, Washington for Zone 2, and Missoula, Montana for Zone 3.

Figure 5.1 illustrutes the process for one particulat optimization run (Climate Zone 1 , RCDP insulation strategies, no blow-in ceiling insulation). The summary table shows:

1. UA

2. $\mathrm{kWH}$

3. $\mathrm{dkWh}$

4. $d \operatorname{Cost}$

5. mills
The overall heat loss rate of the home after the particular conservation measure is applied.

The simulated heat energy reguirements after the particular conservation mensure is applied.

The savings in heal energy resulting from the application of the particular conservation measure.

The cost of the particular conservation measure.

The cost-benefit satio for the particular conservation measure in $\$ / 10()() \mathrm{kWh}$.

The base case assumptions are included at the top of the figure including the base heat loss rate (UA) and anmun heat ene:sy repuirement in $\mathrm{kWh}$. 


\begin{tabular}{|c|c|c|c|c|c|c|}
\hline \multicolumn{7}{|c|}{$\begin{array}{c}\text { Figure } 5.1 \\
\text { Sample Optimization Output }\end{array}$} \\
\hline \multicolumn{7}{|c|}{$\begin{array}{l}\text { Marginal Cost Analysis for Climate Zonc } 1 \\
\text { Basic Run }\end{array}$} \\
\hline \multicolumn{7}{|c|}{ Location: SEA'T'LE, WASHINGTON } \\
\hline \multicolumn{7}{|c|}{$\begin{array}{l}\text { Base Case UA . } 534.4 \\
\text { Base Case annual heating kWh - } 14(0.34\end{array}$} \\
\hline \multicolumn{7}{|c|}{ Base Case Component Speciflcations \& Nominal R-Values } \\
\hline \multicolumn{7}{|c|}{$\begin{array}{l}\text { HEATING SYSTEM: Electric Resistance } \\
\text { DUCT Unwrapped } \\
\text { INFILTRATION } 0.35 \text { ACH } \\
\text { DOOR R-5 } \\
\text { WALL R-11 } \\
\text { WINDOW R-1.33 } \\
\text { FLOOR R-() joisi/R-7 belly blanket } \\
\text { ATTIC R-14 } \\
\text { VAULT R-14 }\end{array}$} \\
\hline Measure & & $\mathrm{UA}$ & kWh & dkWh & dCost & mills \\
\hline$\overline{\text { DUCTT }}$ & SOUND & 534.41 & 1.35() 2 & 5.32 .2 & 10 & 0.77 \\
\hline DUCT & R4 & 5.34 .41 & 1301.5 & $487 .()$ & 21 & 1.76 \\
\hline SPECFIR & $R() / R \mid 1$ & 5()$(9.75$ & 11969 & 104.5 .9 & 134 & 5.24 \\
\hline WALL & R19 & 482.26 & 10024 & 1044.7 & 243 & 9.49 \\
\hline SPECFLR & $R \backslash 1 / R \backslash 1$ & 427.51 & 0282 & 1642.1 & 388 & 9.6 .5 \\
\hline ATTIC & $R ! !$ & 419.19 & 896.5 & $3 ! 6.9$ & 98 & 12.60 \\
\hline VAUI:I' & R19 & 410.88 & 80.50 & 31.5 .6 & 98 & 12.71 \\
\hline AT'IIC & R.30 & $4(01.79$ & $83(16$ & 34.3 .4 & $2(1) 4$ & 24.26 \\
\hline VAULT & $R .30$ & 393.47 & 7903 & 31.3 .1 & 234 & 3() .55 \\
\hline SPECFLR & R22/R II & 379.18 & 7570 & 422.8 & 388 & 37.48 \\
\hline WINDOW & VINYL & 33.3 .96 & $59(1)$ & 1601.4 & 1623 & 39.87 \\
\hline WINDOW & $\triangle R G O N$ & .324 .90 & 5588 & 32() .8 & 218 & 27.68 \\
\hline WALL & R22 & 322.87 & .551 .3 & 75.3 & 8.1 & 45.82 \\
\hline SPECFLR & R22/R22 & .317 .11 & 5217 & 295.6 & 388 & 53.59 \\
\hline VAUL.'T & R.38BAl: & 314.85 & 51.39 & 78.8 & 1.36 & $7(0.47$ \\
\hline A'T"l'IC & R.38 & 312.58 & .5() 6() & 78.7 & 151 & 78.40 \\
\hline A'T'IC & RAS & .309 .56 & 49.54 & 10.5 .4 & 212 & $82 .()()$ \\
\hline A'I"IIC & 1252 & 308.81 & 4928 & 20.2 & 5.3 & 82.44 \\
\hline SYSIEM & HI:A'PUMP & 308.81 & $23(1.3$ & 2625.6 & 6.572 & 102.17 \\
\hline
\end{tabular}




\begin{tabular}{|c|c|c|c|c|c|c|}
\hline \multirow[b]{3}{*}{ Component } & \multicolumn{5}{|c|}{$\begin{array}{l}\text { Table } 5.5 \\
\text { Conservation Options } \\
\text { Cor Cost Optimization }\end{array}$} & \\
\hline & \multirow[b]{2}{*}{ Option } & \multirow{2}{*}{ 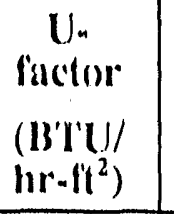 } & \multirow{2}{*}{$\begin{array}{l}\text { Cost } \\
\left(\$ / \mathrm{It}^{2}\right)\end{array}$} & \multicolumn{3}{|c|}{$\begin{array}{l}\text { Mills/kwIl for } \\
\text { Climate Zones }\end{array}$} \\
\hline & & & & 1 & 2 & 3 \\
\hline Window & $\begin{array}{l}\text { Vinyl Frame } \\
\text { Argon Filled Vinyl Frame }\end{array}$ & $\begin{array}{r}.45 \\
.30 \\
\end{array}$ & $\begin{array}{l}10.82 \\
12.27 \\
\end{array}$ & $\begin{array}{l}39,9 \\
27.7 \\
\end{array}$ & $\begin{array}{l}29.3 \\
20.0 \\
\end{array}$ & $\begin{array}{l}25.2 \\
17.1 \\
\end{array}$ \\
\hline Wall & $\begin{array}{l}R-19 \\
R-22\end{array}$ & $\begin{array}{l}.062 \\
.0601 \\
\end{array}$ & $\begin{array}{r}.23 \\
.31 \\
\end{array}$ & $\begin{array}{r}9.5 \\
46.1 \\
\end{array}$ & $\begin{array}{r}7.3 \\
32.8 \\
\end{array}$ & $\begin{array}{r}6.3 \\
28.1 \\
\end{array}$ \\
\hline Floor & $\mid \begin{array}{ll}\text { R-11 } & \text { Belly } \\
\text { R-11 Belly, R-11 Cavity } \\
\text { R-11 Belly, R-22 Cavity } \\
\text { R-22 Belly, R-22 Cavity } \\
\text { R-11 Cut In } \\
\text { R-19 Cul In } \\
\text { R-22 Cul In } \\
\text { R-33 Cul In }\end{array}$ & 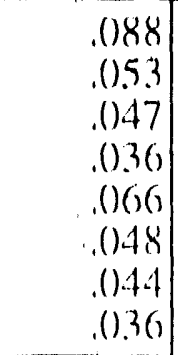 & $\begin{array}{l}.09 \\
.35 \\
.61 \\
.87 \\
.09 \\
.28 \\
.35 \\
.61\end{array}$ & $\begin{array}{r}5.2 \\
9.7 \\
37.5 \\
53.6 \\
4.9 \\
1(0.5 \\
19.7 \\
38.6\end{array}$ & $\begin{array}{r}3.9 \\
7.8 \\
28.8 \\
34.0 \\
3.7 \\
7.7 \\
14.5 \\
27.8\end{array}$ & $\begin{array}{r}3.4 \\
6.8 \\
24.9 \\
28.7 \\
3.2 \\
6.6 \\
12.5 \\
23.9\end{array}$ \\
\hline $\begin{array}{l}\text { Ceiling } \\
\text { (Attic) }\end{array}$ & $\begin{array}{l}R-19 \text { Ball } \\
R-3() \text { Ball } \\
R-38 \text { Ball } \\
R-49 \text { Ball } \\
R-52 \text { Balt } \\
R-49 \text { Blown In }\end{array}$ & 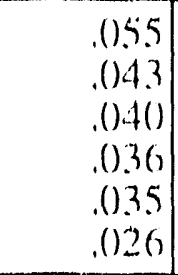 & $\begin{array}{l}.13 \\
.40 \\
.60 \\
.88 \\
.95 \\
.44\end{array}$ & $\begin{array}{r}12.7 \\
24.3 \\
78.4 \\
82.0 \\
82.4 \\
2.8\end{array}$ & $\begin{array}{r}9.5 \\
18.2 \\
141.7 \\
148.2 \\
148.9 \\
2.0\end{array}$ & $\begin{array}{r}8.2 \\
1.5 .6 \\
48.6 \\
124.3 \\
125.0 \\
1.8\end{array}$ \\
\hline $\begin{array}{l}\text { Ceiling } \\
\text { (Vaulted) }\end{array}$ & $\begin{array}{l}\mathrm{R}-19 \text { Batl } \\
\mathrm{R}-3(\mathrm{~B}) \text { Batl } \\
\mathrm{R}-38 \text { Baffle } \\
\mathrm{R}-38 \text { Blown In } \\
\end{array}$ & $\begin{array}{l}.05 .5 \\
.04 .3 \\
.041 \\
.035 \\
\end{array}$ & $\begin{array}{l}.13 \\
.44 \\
.62 \\
.31 \\
\end{array}$ & $\begin{array}{l}12.7 \\
30.5 \\
7(0.5 \\
1(0.3 \\
\end{array}$ & $\begin{array}{r}9.5 \\
22.8 \\
5(1.6 \\
7.7 \\
\end{array}$ & $\begin{array}{r}8.2 \\
19.6 \\
43.5 \\
6.6 \\
\end{array}$ \\
\hline Ducts & $\begin{array}{l}\text { R-4 } \\
\text { Sound* }\end{array}$ & & $\begin{array}{l}31 . \text { home } \\
\text { 10./home }\end{array}$ & $\begin{array}{l}1.77 \\
0.77 \\
\end{array}$ & $\begin{array}{l}1.16 \\
0.52 \\
\end{array}$ & $\begin{array}{l}1 .(1) 1 \\
0.45\end{array}$ \\
\hline $\begin{array}{l}\text { Heating } \\
\text { System }\end{array}$ & Heat Pump & & 5431 / /home & 102.2 & 56.3 & 49.4 \\
\hline
\end{tabular}




\subsubsection{Results}

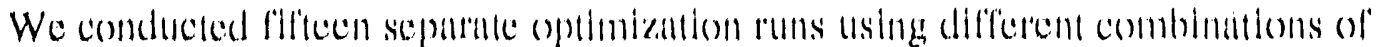

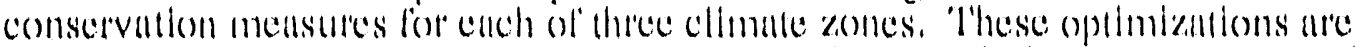

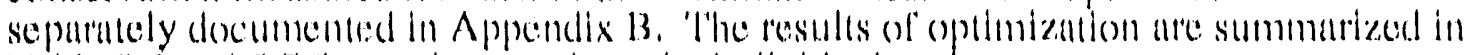
Table 5.6 and 5.7 for packages where the individual optlmum onmponents are dociunented.

Several packages which included the heme pump in the base case saved substantally more energy than the other packnges in every case but Zone 3. In \%one 3, he heal pump was an ophlinum conservation mensure when applied to the base case and slnce fl entered the packige as the least costerfective option, all of the available conservation upgrades were included in the optimum packuge. As a result, when the hent pump option is used in the base case from the starl, the more expensive conservaltom measures such as window conservalion mensures ate climinated firom the optimum conservation package. 'This pattern is repeated in all climales bul only in Zone 3 is the resull a lower energy savings lotul.

for manufinedured homes built using conventional floor construction methods, the optimum packinge uses an R-22 belly blanked and R-22 convily insulation in Zones 2 and 3 and R-11 cavily insulation and an R-11 belly blanke for the hen pump cases. When the optimization is re-ron using an improved floor system (with belly insulation ent in to the first l beam and no floor jost insulation over the dact) al substantial improvement in the

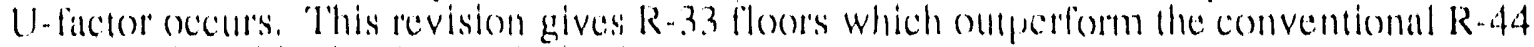
floors included in the first optimizantion.

Duce insulation is by far the most costeffective option available to the manufactured home builders. Duet insulallon is included in all the optimizalions and thus duet losses which callse substantial reduction in the U-factor have been eliminated form the optimization, $\wedge$ yuick review of the floor U-fitcors in lable 3.2 shows that without this assimption, the improved floor systems would be substantially less effective. The cost-effectiveness of duct insulation suggessts that it should be a reguired part of SGC packages.

Separate runs were conducted for the blow-in insulation in the attics since only iwo plants have the capability of using this type of insulation. 'I'his option results in similar conservaltion levels for ceilings all a much lower cost than ball insulation.

We assumed that manufacturers using fiberglass balls would sed the batts away from the edge of the ceiling to preserve ceiling ventilition. I lowever, one manufacturer uses a cardboard balfle which allows him on place the balls over the entire widh of the ceiling and push the batt down to preserve the ventilation space all the edge. This makes a substantial difference in the U. fiecter and becomes an optimum method for achieving insulation when R-values above R-3() are used.

The optimization was run using wall insulation stralegies that had $2 \times 6$ wall construction as part of the base case. 'lhus the additional wall insulation is extremely cost-effective in all cases. In some of the colder climales, R-22 walls alle more cost-eflective where the batts are crushed into the existing $2 \times 6$ wall to improve its performance. Some manufacturers used $2 \times 4$ walls with $R-11$ balls in their base models. We reviewed this approach separately (see Appendix ('). The retail price of an $R-19$ wall in these cases is 


\begin{tabular}{|c|c|c|c|c|c|c|c|c|c|}
\hline \multicolumn{10}{|c|}{$\begin{array}{c}\text { T'able } 5.6 \\
\text { Optimumin Package } \\
\text { Conventional Floors } \\
\text { Nominal R-Values }\end{array}$} \\
\hline Zone & $\begin{array}{l}\text { Average } \\
\text { Savingss }\end{array}$ & Wall & \multicolumn{2}{|c|}{ Floor } & \multirow{2}{*}{$\frac{\text { Window }}{\text { (U-finctor) }}$} & \multicolumn{2}{|c|}{ Ceilling } & Ducts & Heat \\
\hline & $(k W h)$ & & Bully & Cuvily & & Altic & Vuult & & \\
\hline 1 & 8.521 & 22 & 11 & 22 & .39 & 3() & 3() & 4 & ER \\
\hline 2 & 11967 & 22 & 22 & 22 & .39 & 30) & $\begin{array}{r}38 \\
\text { Bullite }\end{array}$ & 4 & $\mathrm{ER}$ \\
\hline 3 & $194(2)$ & 22 & 22 & 22 & .39 & 38 & $\begin{array}{r}38 \\
\text { Bu'llo }\end{array}$ & 4 & $\mathrm{HP}$ \\
\hline \multicolumn{10}{|c|}{ Ileut P'ump l'ackage } \\
\hline 1 & 10338 & 19 & 11 & 11 & Busc & 19) & 19 & 4 & $H P$ \\
\hline 2 & $15(1) 37$ & 19) & 11. & 11 & Buse: & 30) & 19) & 4 & $\mathrm{HP}^{\mathrm{P}}$ \\
\hline 3 & 17322 & 19) & 11 & 11 & .39 & 30) & 30) & 4 & $\mathrm{HP}$ \\
\hline \multicolumn{10}{|c|}{ Blown Allics * } \\
\hline 1 & 9060 & 22 & 19) & 22 & .39 & 49 & 38 & 4 & ER \\
\hline 2 & $126(0) 3$ & 22 & 22 & 22 & .39) & 49 & 38 & 4 & $\mathrm{ER}$ \\
\hline 3 & 10518 & 22. & 22 & 22 & .39 & 4!) & 38 & 4 & $\mathrm{HP}$ \\
\hline
\end{tabular}

\begin{tabular}{|c|c|c|c|c|c|c|c|c|}
\hline \multicolumn{9}{|c|}{$\begin{array}{c}\text { Table } 5.7 \\
\text { Optimum Package } \\
\text { Optimum Floor Construction (Cut-In Belly Insulation) } \\
\text { Nominal R-Values }\end{array}$} \\
\hline Zone & $\begin{array}{l}\text { A vernge } \\
\text { Savinghis }\end{array}$ & Wall & Floor & Window & \multicolumn{2}{|c|}{ Ceiling } & Ducts & Ileat \\
\hline & & & Belly & (U-fiactor) & Altic & Vault & & \\
\hline 1 & 7829 & 22 & 3.3 & .39 & 30 & 30 & 4 & ER \\
\hline 2 & 106.50 & 22 & 33 & .39 & 30 & 30 & 4 & ER \\
\hline 3 & 17878 & 22 & 33 & .39) & 3() & 38 & 4 & IIP \\
\hline \multicolumn{9}{|c|}{ Heat Pump Packange } \\
\hline 1 & 0,417 & 19) & 19) & Basc & 19) & 19 & 4 & IIP \\
\hline 2 & 13981 & 19 & 22 & Basse & 30 & 19) & 4 & HP \\
\hline 3 & $10,3.35$ & 19 & 22 & Basce & $3(0)$ & 30 & 4 & $H P$ \\
\hline
\end{tabular}

about 2.5 times greater than the priee when manufacturers use $2 \times 6$ for wall framing. Nevertheless, this change resulded in virtually identical optimum conservation packages except where heat pumps were incladed in Climate Zone 1. 
The effect of the heat pump on the optimization is substantial, especially in Zones 1 and 2. It should be pointed out that when the heat punyp is included in the optimizations in competition with all conservation options, the marginal cost of the heal pump is predicted at 1(02 mills in Zone 1 and 56 mills in Zone 2 (as shown in Appendix B). In both cases, the heat pump fails to meet the 52 mill ceiling for inclusion in the optimum package. The heat pump does, however, save substantially more energy than any other measure in the package and thus, when it is included in the package, the amount of energy saved is substantially greater than when only envelope measures are employed. But it is not cost effective in Climate Zones 1 and 2.

We looked at only two window measures in the optimization runs: vinyl-frame windows and vinyl-frame windows with argon fill. The thermally-broken aluminum windows performed worse and cost more than any of the other windows and thus were excluded at the start of the optimization runs. The storm windows had aominally equivalent performance for less cost than the vinyl windows, although it was our judgement that the use of storm windows decreases the quality of the window. In all cases the argon-filled windows were the preferred window option. The incremental savings from argon windows are almost twice that from plain vinyl windows.

Attic and ceiling insulation optimized at about $\mathrm{R}-3($ ) except in the coldest climates. This is somewhat below the SGC specifications and reflects the relatively poor performance of ceiling batt insulation due to the current manufacturing practices in this industry. At a minimum, manufacturers should be required to use insulation baffle and encouraged to switch to blow-in attic insulation. When blow-in insulation is used, much higher $R$-values are cost-effective in the optimization.

The floor insulation strategies recommended in the SGC specifications should be revised dramatically. Manufacturers should change the placement of the belly blanket. The belly blanket should be cut and lifted into the joist cavity above the outriggers and I-beams and extended below the duct at full depth. This improves floor insulation performance dramatically and is similar to base case manufacturing technigues. Duct insulation is cost-effective in all floor insulation strategies reviewed.

The optimization analysis recommended optimum packages somewhat different from those in the current SCC specifications. This suggests that more careful attention should be paid to the U-factors which can be achieved given the construction practices in this industry. Savings are equally important, since base case homes are not affected by local and state energy codes and the standards set by HID are dramatically below the optimal package described here. A careful review of the specifications seems warranted.

Manufacturers would benefit from assistance in improving detailing and manufacturing techniques. Figher levels of energy efïiciency than commonly obtained should be cost-effective, specifically the use of blow-in insulation technicyues. The use of duct insulation should be reguired by the SGC specifications since it increases overall performance about $16 \%$ at a minimal cost in all homes, whether they have heat pumps or electric resistance heat. 


\section{References}

Air-Conditioning and Refrigeration Institute. 1989. Directory of certified unitary air-conditioners, unitary air-source heat pumps and sound-rated outdoor unitary equipment. Arlington, Virginia: ARI.

American Society of Heating, Refrigeration and Air Conditioning Engineers (ASHRAE). 1989. Handbook of Fundamentals. Atlanta, Georgia: ASHRAE.

Baylon, David, Mike Lubliner and Bob Davis. 1990. Manufactured Homes Cost Data Analysis Report. For Bonneville Power Administration, Portland, Oregon.

Baylon, David and Jon Heller. 1988. Super Good Cents Heat Loss Reference. Prepared by Ecotope for Bonneville Power Administration, Portland, Oregon.

James, Ruth Ann. March, 1990. Personal communication.

Kennedy, Michael. 1990. Documentation for Simplified Heating System Equipment Model. Prepared $b_{y}$ Zcotope for Washington State Energy Office, Olympia, Washington.

Modera, M. 1989. Residential duct system leakage: Magnitude, impacts and potential for reduction. LBL,-26575, Lawrence Berkeley Laboratory, Berkeley, California.

Palmiter, Larry and David Baylon. 1982. Potential for Conservation for Electrical Energy in Northwest Residences. Battelle Pacific Northwest Laboratories, Richland, Washington.

Palmiter, Larry and Michael Kennedy. 1983. Assessment of electric power conservation and supply resources in the Pacific Northwest, Volume I, Supplement A: Heat pumps in residential buildings. Prepared by Battelle Pacific Northwest Laboratories for the Pacific Northwest Electric Power and Conservation Planning Council, Portland, Oregon.

Robison, D.H. and L.A. Lambert. 1989. Field investigation of residential infiltration and heating duct leakage. ASHRAE Transactions 95:2.

Weakley, S., R. Eckert \& A. Lee. 199(). Cost Data Collection for Manufactured Homes in the Residential Construction Demonstration Praject. Portland, Oregon: Bonneville Power Administration: 
7 Appendix A

Prototype Manufactured Home 


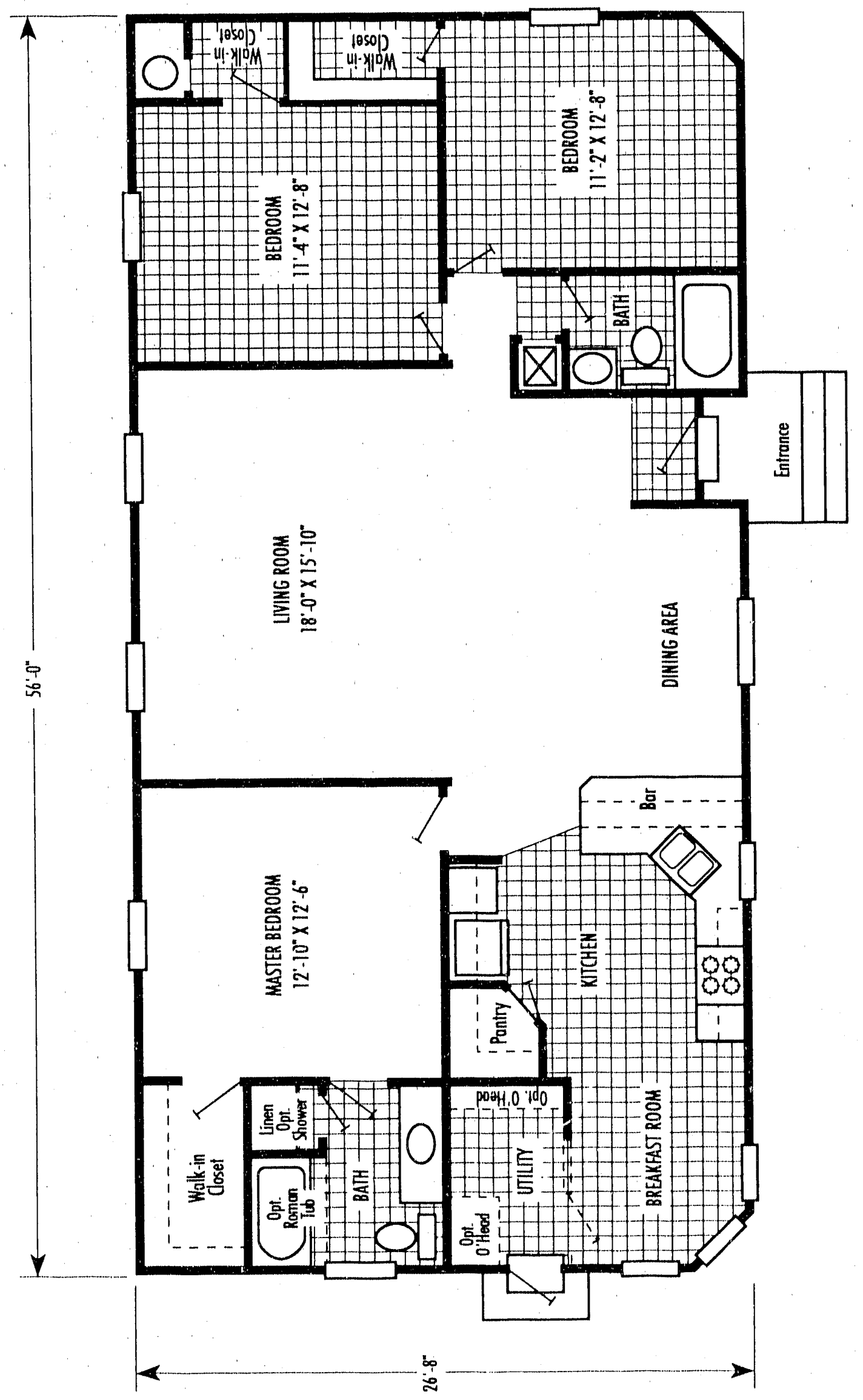





营 

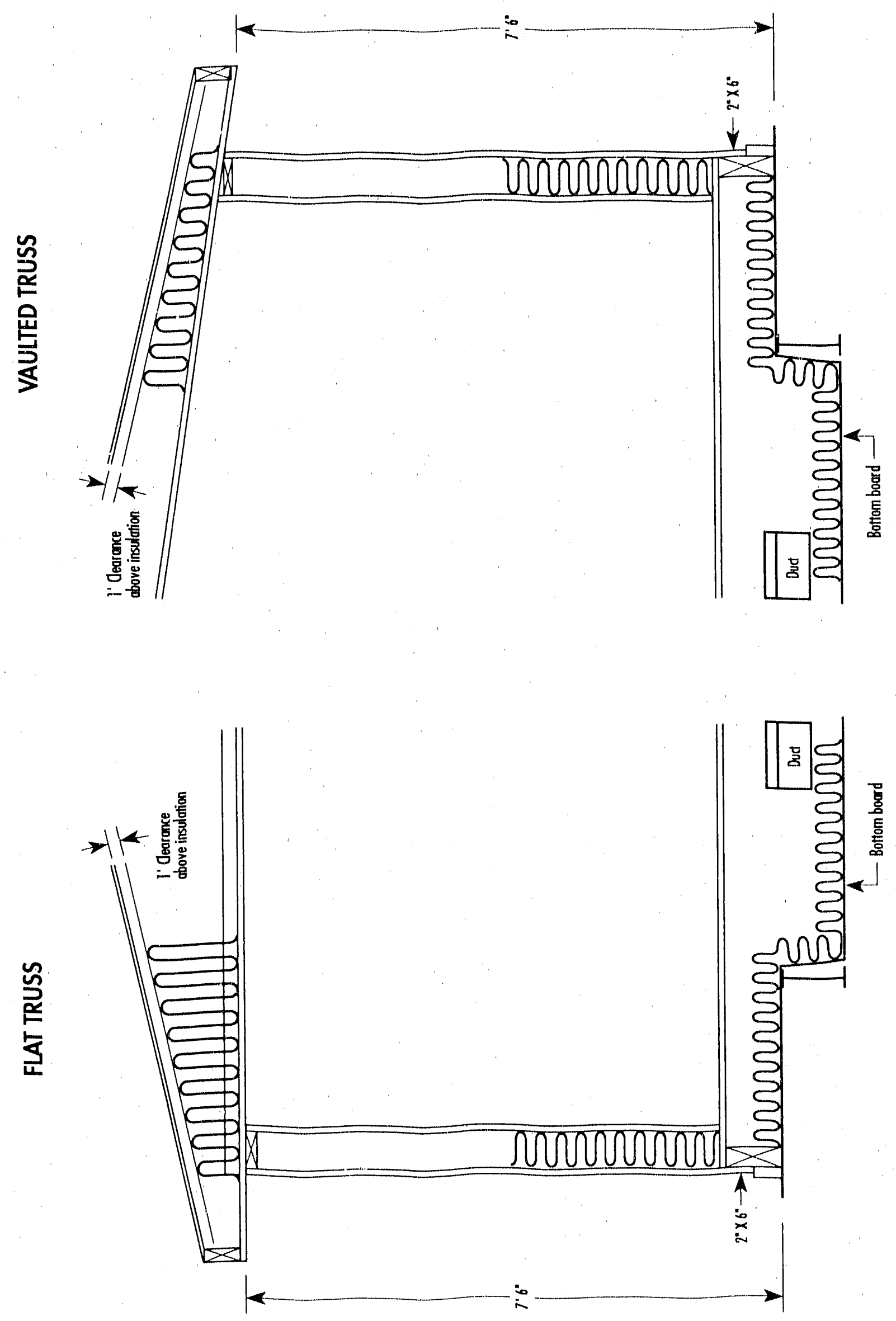

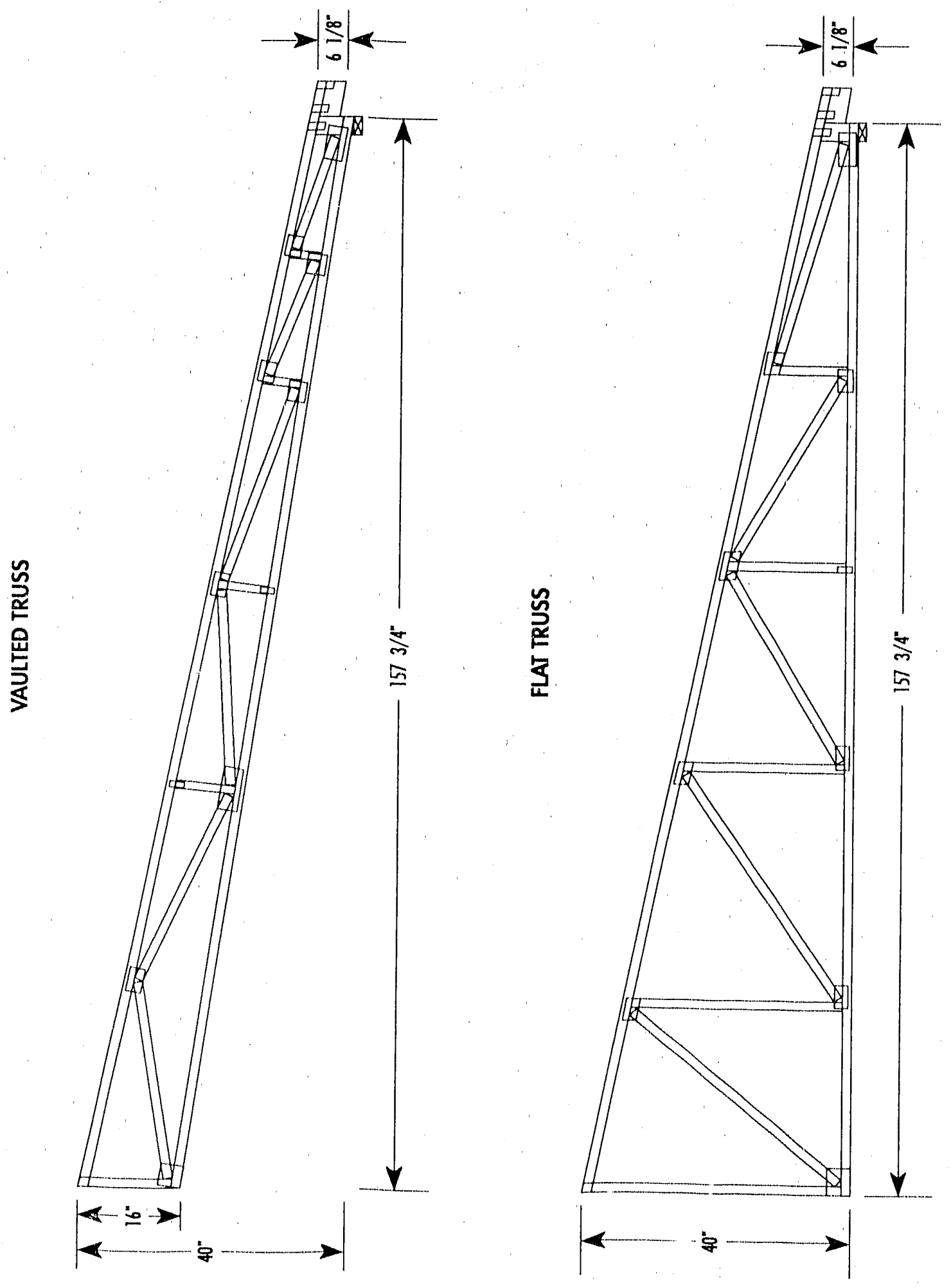
8 Appendix B

Appendix B

Optimization Runs 


\section{Marginal Cost Analysis for Climate Zone 1 Basic Run}

L.ocation: SEATTLE, WASHINGTON

Base Case UA - 534.4

Base Case annual heating kWh - 14034

Base Case Component Specifications \& Nominal R-Values

HEATING SYSTEM: Electric Resistance

DUCT Unwrapped

INFILTRATION $0.35 \mathrm{ACH}$

DOOR R-5

WALL R-11

WINDOW R-1.33

FLOOR R-() joist/R-7 belly blanket

ATTIC R-14

VAULT R-14

\begin{tabular}{|c|c|c|c|c|c|c|}
\hline Measure & & UA & $k W h$ & $\mathrm{dkWh}$ & $d \cos t$ & mills \\
\hline DUCT & SOUND & 534.41 & 135() 2 & 532.2 & 10) & 0.77 \\
\hline DUCT & R4 & 534.41 & 13015 & 487.0 & 21 & 1.76 \\
\hline SPECFLR & $\mathrm{R}(\mathrm{)} / \mathrm{R} 11$ & $5(0) .75$ & 11969 & 1045.9 & 1.34 & 5.24 \\
\hline WALL & R19 & 482.26 & 10924 & 1044.7 & 243 & 9.49 \\
\hline SPECFLR & $\mathrm{R} 11 / \mathrm{R} 11$ & 427.51 & 9282 & 1642.1 & 388 & 9.65 \\
\hline ATTIC & R 19 & 419.19 & 8965 & 316.9 & 98 & 12.66 \\
\hline VAULT & R19 & 410.88 & 86.50 & 315.6 & 98 & 12.71 \\
\hline ATTIC & R30) & 401.79 & 8306 & 343.4 & 204 & 24.26 \\
\hline VAULT & $\mathrm{R} 30$ & 39347 & 7993 & 3131 & 234 & 30.55 \\
\hline SPECFLR & $\mathrm{R} 22 / \mathrm{R} 11$ & 379.18 & 757() & 422.8 & 388 & 37.48 \\
\hline WINDOW & VINYL & 333.96 & 5909 & 1661,4 & 1623 & 39.87 \\
\hline WINDOW & ARGON & 324.99 & 5588 & 320.8 & 218 & 27.68 \\
\hline WALL & R22 & 322.87 & 5513 & 75.3 & 84 & 45.82 \\
\hline SPECFLR & $\mathrm{R} 22 / \mathrm{R} 22$ & 317.11 & 5217 & 295.6 & 388 & 53.59 \\
\hline VAULT & R38BAF & 314.85 & 5139 & 78.8 & 136 & $7(0.47$ \\
\hline ATTIC & R38 & 312.58 & $5(06)$ & $7: 37$ & 151 & 78.40 \\
\hline ATTIC & R49 & $3(1) 9.56$ & 49.54 & 105.4 & 212 & $82.0 \%$ \\
\hline ATTIC & R52 & $3(1) 8.81$ & 4928 & 26.2 & 53 & 82.44 \\
\hline SYSTEM & HEATPUMP & $3(1) 8.81$ & 2303 & 2625.6 & 6.572 & $1(02.17$ \\
\hline
\end{tabular}




\section{Marginal Cost Analysis for Climate Zone 2 \\ Basic Run}

Locution: SPOKANE, WASHINGIION

Base Case UA - $\quad 534.4$

Base Case annual heating $\mathrm{kWh}$ - 20844

Base Case Component Specifications \& Nominal R-Values

HEATING SYS'TEM: Electric Resistance

DUCT Unwrapped

INFILTRATION $(0.35 \mathrm{ACH}$

DOOR R-5

WALL R-11

WINDOW R-1.33

FLOOR R-() joist/R-7 belly blanket

ATTIC R-14

VAULT R-14

\begin{tabular}{|c|c|c|c|c|c|c|}
\hline Measure & & UA & kWh & dk Wh & dCost & mills \\
\hline DUCT & SOUND & 534.41 & 20061 & 783.4 & 10 & 0.52 \\
\hline DUCT & R4 & 534.41 & 19325 & 73.5 .9 & 21 & 1.16 \\
\hline SPECFLR & $\mathrm{R}() / \mathrm{R} 11$ & 5() 9.75 & 17932 & 1.392 .5 & 134 & 3.94 \\
\hline WALL & R 19 & 482.26 & 16.568 & 1364.9 & 243 & 7.26 \\
\hline SPECFLR & $\mathrm{R} 11 / \mathrm{R} 11$ & 427.51 & 14529 & 2() 38.1 & 388 & 7.77 \\
\hline ATTIC & R19 & 419.19 & 14107 & 422.6 & 98 & 9.49 \\
\hline VAULT & R 19 & 410.88 & 13686 & 420.4 & 98 & 9.54 \\
\hline ATTIC & R30) & 401.79 & 13228 & 458.6 & 204 & $18.1 \%$ \\
\hline VAULT & R30 & 393.47 & $128(08$ & 420.2 & 234 & 22.76 \\
\hline WINDOW & VINYL & 348.26 & 10550 & 2257.5 & 1623 & 29.34 \\
\hline WINDOW & ARGON & 339.28 & 10107 & 443.0 & 218 & 20.04 \\
\hline SPECFLR & R192/R 11 & 324.90 & 9558 & 549.7 & 388 & 28.83 \\
\hline WALL & R22 & 322.87 & 9452 & 105.3 & 84 & 32.75 \\
\hline SPECFLR & R22/R22 & 317.11 & 8987 & 46.5 .5 & 388 & 34.04 \\
\hline VAULT & R38BAF & 314.85 & 8877 & 109.9 & 136 & $\tilde{7}() .5 .5$ \\
\hline SYSTEM & HEATPUMP & 314.8 .5 & 4111 & 4766.2 & 6.572 & 56.28 \\
\hline ATTIC & R38 & 312.58 & $4(067$ & 43.6 & 151 & 141.66 \\
\hline ATTIC & R49 & $3(1) 9.56$ & $4(1)(19$ & 58.3 & 212 & 148.15 \\
\hline ATTIC & $\mathrm{R} 52$ & 3() 8.81 & 3994 & 14.5 & 53 & 148.93 \\
\hline
\end{tabular}




\section{Marginal Cost Analysis f'or Climute Zone 3 Basic RuII}

Location: Missoula, Montuna

Buse Case UA - 534.4

Base Case annual heating kWh . 24429

Base Case Component Specifications \& Nominai R-Values

HEATING SYSTEM: Electric Resistance

DUCT Unwrapped

INFILTRRATION $0.35 \mathrm{ACH}$

DOOR R-5

WALL R-11

WINDOW R-1.3.3

FLOOR R-() joist/R-7 belly blankel

A'TTIC R-14"

VAULT R-14

\begin{tabular}{|c|c|c|c|c|c|c|}
\hline Measure & & UA & $\mathrm{kWh}$ & alkWh & dCost & mills \\
\hline DUC'T & SOUND & 534.41 & 23526 & $9(1) 2.7$ & 10) & $(0.45$ \\
\hline DUC' & R4 & 534.41 & 22675 & 8.51 .1 & 21 & 1.01 \\
\hline SPECFILR & $R() / R \mid 1$ & 5() 9.75 & 2107.5 & 1599.9 & 134 & 3.43 \\
\hline WALL. & R 19 & 482.26 & 19509 & 1.566 .2 & 243 & 6.33 \\
\hline SPECFLR & $R \mid 1 / R 11$ & 427.51 & 17177 & 2332.6 & 388 & 6.79 \\
\hline ATIIC & R 19 & 419.19 & 166887 & 49() .1 & 98 & 8.18 \\
\hline VAULI' & R 19 & 410.88 & 16197 & 489.3 & 98 & 8.20 \\
\hline ATTIC & $\mathrm{R} 3()$ & 4() 1.79 & 15664 & 53.3 .6 & 2() 4 & 15.61 \\
\hline VAULT & R30) & 39) 3.47 & 1.5176 & 487.6 & 2.34 & 19.62 \\
\hline WINDOW & VINYL & 348.26 & 12543 & $26,33.3$ & 1623 & 25.16 \\
\hline WINDOW & ARGON & 339.28 & 12() 24 & 518.6 & 218 & 17.12 \\
\hline SPECFLR & R22/R11 & 324.99 & 11.389 & 6.35 .5 & 388 & 24.93 \\
\hline WALL & $R 22$ & 322.87 & 11266 & 122.9 & 84 & 28.0 .5 \\
\hline SPECFIR & R22/R22 & 317.11 & 10714 & 5.52 .1 & .388 & 28.70 \\
\hline VAUL'T' & R.38BAI: & 314.85 & 10586 & 127.6 & 1.36 & 43.53 \\
\hline ATTIC & R38 & 312.58 & 104.50 & 127.1 & 1.51 & 48.5 .5 \\
\hline SYSTEM & HEATPUMP & 312.58 & 5() 27 & 54.31 .7 & 6.572 & 49.39 \\
\hline ATIIC & R49 & $3(49.56$ & 4958 & 69.5 & 212 & 124.29 \\
\hline A'TTIC & $\mathrm{R} .52$ & 3() 8.81 & 4941 & 17.3 & 53 & 12.5 .0 .3 \\
\hline
\end{tabular}




\section{Marginal Cost Analysis for Climate Zone 1 Heut P'unip-()nly (Cusc}

Location: SEATTLE, WASHIINGTON

Base Case UA - 534.4

Base Case annual heating kWh - 5581

Base Case Component Spedifintons \& Nominal R-Values

HEATING SYSTEM: Heat PUInp

DUCT Unwrapped

INFILTRATION $\quad 0.35 \mathrm{ACH}$

DOOR R-5

WALL R-11

WINDOW R-1.33

FLOOR R-() joist/R-7 belly blunket

ATTIC R-14

VAULT' R-14

\begin{tabular}{|c|c|c|c|c|c|c|}
\hline Measure & & $\mathrm{UA}$ & $k W h$ & dlkWh & $d$ Cost & mills \\
\hline DUCT & SOUND & 534.41 & 5392 & 188.3 & 10) & 2.17 \\
\hline DUCT & R4 & 534.41 & .5217 & 175.6 & 21 & 4.88 \\
\hline SPECFLR & $\mathrm{R}(0) / \mathrm{R} \|$ & $5(09.75$ & 4849 & 367.3 & 1.34 & 14.93 \\
\hline WALL & R 19 & 482.26 & 4492 & 357.3 & 243 & 27.75 \\
\hline SPECFLR & $\mathrm{R}\|/ \mathrm{R}\|$ & 427.51 & 3923 & 568.9 & 388 & 27.85 \\
\hline ATTIC & R 19 & 419.19 & 3810 & 113.6 & 98 & 35.32 \\
\hline VAULT & R19 & 410.88 & 3696 & 113.5 & 98 & 35.34 \\
\hline ATTIC & R30 & 401.79 & 3572 & 124.0 & 2() 4 & 67.21 \\
\hline VAULT & R3() & 393.47 & 3459 & 113.4 & 234 & 84.33 \\
\hline WINDOW & VINYL & 348.26 & 2846 & 612.7 & 1623 & 108.12 \\
\hline WINDOW & ARGON & 339.28 & 2724 & 122.1 & 218 & 72.71 \\
\hline SPECFLR & $R 22 / R \|$ & 324.90 & 2567 & 157.0 & 388 & 100.94 \\
\hline WALL & R22 & 322.87 & 2538 & 20.0) & 84 & 118.78 \\
\hline SPECFLR & $\mathrm{R} 22 / \mathrm{R} 22$ & 317.11 & 2415 & 122.6 & 388 & 129.28 \\
\hline VAULT & $\mathrm{R} 38 \mathrm{BAF}$ & 314.85 & 2385 & 3()$, 6$ & 136 & 181.26 \\
\hline ATTIC & R38 & 312.58 & 2354 & 30.7 & 151 & 20121 \\
\hline ATTIC & R49 & 300.56 & 2313 & 41.2 & 212 & $2(09.89$ \\
\hline
\end{tabular}




\section{Marginal Cost Analysis for Climate Zone 2 \\ IIent P'unpe()nly Case}

Locution: SPOKANE, WASHING'ION

Base Case UA - 534.4

Base Case unnual heuting $\mathrm{kWh}$ - 8954

Base Case Component Specificutions \& Nominal R-Values

HEATINO SYSTEM: Heat Pump

DUCT Unwrupped

INFILTRATION $0.35 \mathrm{ACH}$

DOOR R-5

WALL R-11

WINDOW R- -1.33

FLOOR R-() joist/R-7 belly blanke

ATTIC R-14

VAULT R-14

\begin{tabular}{|c|c|c|c|c|c|c|}
\hline Measure & & UA & kWh & $\mathrm{dkWh}$ & $\mathrm{dCost}$ & mills \\
\hline DUCT & SOUND & 534.41 & 8576 & 377.8 & 10 & 1.08 \\
\hline DUCT & R4 & 534.41 & 8239 & 336.7 & 21 & 2.55 \\
\hline SPECFLR & $R(0 / R \mid 1$ & $.5(1) 9.75$ & 76.36 & $6(1) 3.8$ & 134 & 9.08 \\
\hline WALL & $\mathrm{R} 19$ & 482.26 & 7127 & 5() 8.2 & 243 & 19.51 \\
\hline SPECFLR & $\mathrm{R}\|\mathrm{R}\| \mathrm{R} \|$ & 427.51 & 6.324 & $8(1) 3.6$ & $38 x$ & 19.72 \\
\hline ATTIC & R 19 & 419.19 & 6157 & 167.3 & 98 & 23.98 \\
\hline VAULT & $R 19$ & 410.88 & 5990 & 166.6 & 98 & 24.08 \\
\hline ATTIC & R30) & $4(1) 1.79$ & 58() 7 & $183 .()$ & 204 & 45.52 \\
\hline VAULT & $\mathrm{R} 30$ & 39) 3.47 & 5678 & 128.9 & 2.34 & 74.21 \\
\hline WINDOW & VINYL & 348.26 & 4766 & 912.0 & 1623 & 72.63 \\
\hline WINDOW & ARGON & 339.28 & 4585 & 180.9 & 218 & 49.07 \\
\hline SPECFLR & $\mathrm{R} 22 / \mathrm{R} 11$ & 324.99 & 4383 & 202.6 & 388 & 78.22 \\
\hline WALL & R22 & 322.87 & 4341 & 41.7 & 84 & 82.68 \\
\hline SPECFLR & $\mathrm{R} 22 / \mathrm{R} 22$ & 317.11 & 4154 & 186.5 & 388 & 84.93 \\
\hline VAULT & $R .38 B A F$ & 314.85 & 4111 & 43.6 & 1.36 & 127.28 \\
\hline ATTIC & R.38 & 312.58 & $4(067$ & 43.6 & 151 & 141.66 \\
\hline ATTIC & R49 & $3(199.56$ & $40(0)$ & 58.3 & 212 & 148.15 \\
\hline ATTIC & R.52 & $3(1) 8.81$ & 3994 & 14.5 & 53 & 148.93 \\
\hline
\end{tabular}




\section{Marginal Cost Analysis fore Climate Zono 3 Ileat Punipu()nly Case}

Location: Missoula, Montana

Base Case UA - 534.4

Base Case anmmal heating kWh - 10812

Base Case Component Specilicutions \& Nominal R-Values

HEATING SYSTEM: HeUt PUIMP

DUCT Unwripped

INFILTRATION (0.35 ACH

DOOR R-5

WALL R-11

WINDOW R $\cdot 1.33$

FLOOOR R-() joist/R-7 belly blanket

A'TTIC R-14

VAUL'T R-14

\begin{tabular}{|c|c|c|c|c|c|c|}
\hline Measure & & $U A$ & $k W h$ & dkWh & dCost & mills \\
\hline DUCT & SOUND & 534.41 & 10361 & 4.50 .7 & 10 & 0.91 \\
\hline DUCT & $\mathrm{R} 4$ & 534.41 & 0064 & 396.9 & 21 & 2,16 \\
\hline SPECFLR & $R() / R \| 1$ & $5(1) 9.75$ & 9253 & 711.6 & 134 & 7.71 \\
\hline WALL & R 19 & 482.26 & 8667 & 586.0 & 243 & 16.92 \\
\hline SPECFLR & $\mathrm{R} 11 / \mathrm{R} \| 1$ & 427.51 & 7725 & 941.9 & 388 & 16.82 \\
\hline ATTIC & R IV & 419.19 & 7525 & 1905 & 98 & 2011 \\
\hline VAULTT & $R \mid 9$ & 410.88 & 7326 & 199.5 & 98 & $2(0.11$ \\
\hline ATTIC & R.30) & $4(01.79$ & 7107 & 219.1 & 2() 4 & 38.03 \\
\hline WINDOW & VINYL & 3.56 .58 & $6(0) 69$ & $1(137.9$ & 1623 & 63.82 \\
\hline WINDOW & ARGON & 347.61 & 58.52 & 217.0 & 218 & 40.91 \\
\hline VAULT & R30) & 339.28 & 56.50 & 201.5 & 234 & 47.47 \\
\hline SPECFLR & $\mathrm{R} 22 / \mathrm{R} \mid 1$ & 324.99 & 5412 & 2.37 .9 & 388 & 66.59 \\
\hline SPECFI,R & $\mathrm{R} 22 / \mathrm{R} 22$ & 319.23 & 5180 & 232.2 & 388 & 68.25 \\
\hline WALL & R22 & 317.11 & 5131 & 48.9 & 84 & 7() .53 \\
\hline VAULT & R38BAF & 314.85 & $5(079$ & 52.1 & 136 & 106.64 \\
\hline ATTIC & R38 & 312.58 & 5() 27 & 52.0 & 151 & 118.78 \\
\hline ATIIC & R49 & $3(1) 9.56$ & 4958 & (6) .5 & 212 & 124.29 \\
\hline ATTIC & R.52 & $3(1) 8.81$ & 49,41 & 17.3 & 53 & 125.03 \\
\hline
\end{tabular}


Marginal Cost Analysis for Climate Zone 1

Basic Run With Blown.in Ceiling Insulation

Location: SEATTLE, WASHINGTON

Base Case UA - 5330.6

Base Case anmual heating kWh - 1.3878

Base Case Component Specifications \& Nominal R-Values

HEATING SYST'GM: Electric Resistunce

DUCT Unwrapped

INFILTRATION $(0.35 \mathrm{ACH}$

DOOR R-5

WALL R-1.1

WINDOW R-1.33

FLOOR R-() joist/R-7 belly blanket

AT"TIC R-14 (blown-in fïberglass)

VAULT R-14 (blown-in tiberglass)

\begin{tabular}{|c|c|c|c|c|c|c|}
\hline Measure & & UA & $k W h$ & $\mathrm{dkWh}$ & $d \operatorname{dcost}$ & mills \\
\hline DUCT & SOUND & 5.30 .63 & 1.3351 & 526.9 & 10) & 0.77 \\
\hline DUCT & R4 & $53(1) .63$ & 12860 & 482.0 & 21 & 1.78 \\
\hline SPECFLR & $R() / R \mid 1$ & $5(05.97$ & 11825 & 1044.0 & 134 & 5.25 \\
\hline WALL & R19 & 478.48 & 10782 & 1043.1 & 243 & 9.50 \\
\hline SPECFLR & R11/R11 & 423.73 & 9138 & 1643.5 & 388 & 9.64 \\
\hline ATTIC & R49BLOW & 373.83 & 7263 & 1015.0 & 333 & 13.37 \\
\hline VAULT & R.38BLOW & $4(0) 1 .(14$ & 8278 & 860.4 & 234 & 11.11 \\
\hline SPECFLR & $\mathrm{R} 22 / \mathrm{R} 11$ & 359.53 & 6841 & 422.1 & 388 & 37.51 \\
\hline WINDOW & VINYL & 314.32 & 5210 & 16.30 .6 & 1623 & 40.59 \\
\hline WINDOW & ARGON & $3(1) 5.34$ & 4893 & 317.4 & 218 & 27.94 \\
\hline WALL & R22 & $3(1) 3.22$ & 4818 & 74.7 & 84 & 46.12 \\
\hline SPECFLR & $\mathrm{R} 22 / \mathrm{R} 22$ & 297.47 & 4535 & 282.9 & 388 & 55.97 \\
\hline SYSTEM & HEATPUMP & 297.47 & 2148 & 2387.3 & 6.57 .2 & 112.28 \\
\hline
\end{tabular}




\section{Marginal Cost Analysis for Climate Zone 2 \\ Basic Run With Blown-in Ceiling Insulation}

Location: SPOKANE, WASHINGTON

Base Cáse UA - 530.6

Base Case annual heating kWh - 20641

Base Case Component Specifications \& Nominal R-Values

HEATING SYSTEM: Electric Resistance

DUCT Unwrapped

INFILTRATION $0.35 \mathrm{ACH}$

DOOR R-5

WALL R-11

WINDOW R-1.33

FLOOR R-() joist/R-7 belly blanket

ATTIC R-14 (blown-in fiberglass)

VAULT R-14 (blown-in fiberglass)

\begin{tabular}{|c|c|c|c|c|c|c|}
\hline Measure & & UA & kWh & dkWh & dCost & mills \\
\hline DUCT & SOUND & 530.63 & 19864 & 777.1 & 10 & 0.53 \\
DUCT & R4 & 530.63 & 19135 & 729.6 & 21 & 1.17 \\
SPECFLR & R(0/R11 & $5(05.97$ & 17745 & 1390.0 & 134 & 3.95 \\
WALL & R19 & 478.48 & 16380 & 1364.7 & 243 & 7.26 \\
SPECFLR & R11/R11 & 423.73 & 14337 & 2042.8 & 388 & 7.76 \\
ATTIC & R49BLOW & 373.83 & 11821 & 1368.5 & 333 & 9.91 \\
VAULT & R38BLOW & 401.04 & 13190 & 1147.5 & 234 & 8.33 \\
WINDOW & VINYL & 314.32 & 9029 & 2256.3 & 1623 & 29.34 \\
WINDOW & ARGON & 305.34 & 8586 & 442.3 & 218 & 20.06 \\
SPECFLR & R22/R11 & 359.53 & 11285 & 536.3 & 388 & 29.52 \\
WALL & R22 & 303.22 & 8482 & 104.2 & 84 & 33.06 \\
SPECFLR & R22/R22 & 297.47 & 8038 & 443.9 & 388 & 35.66 \\
SYSTEM & HEATPUMP & 297.47 & 3776 & 4262.4 & 6572 & 62.88 \\
\hline
\end{tabular}




\section{Marginal Cost Analysis for Climate Zone 3 \\ Basic Run With Blown-in Ceiling Insulation}

Location: Missoula, Montana

Base Case UA - 530.6

Base Case annual heating $\mathrm{kWh}$ - 24198

Base Case Component Specifications \& Nominal R-Values

HEATING SYSTEM: Electric Resistance

DUCT Unwrapped

INFILTRATION $0.35 \mathrm{ACH}$

DOOR R-5

WALL R-11

WINDOW R-1.33

FLOOR R-() joist/R-7 belly blanket

ATTIC R-14 (blown-in fiberglass)

VAULT R-14 (blown-in fiberglass)

\begin{tabular}{|c|c|c|c|c|c|c|}
\hline Measure & & UA & $\mathrm{kWh}$ & dkWh & dCost & mills \\
\hline DUCT & SOUND & 53() .63 & 23303 & 895.6 & 10 & 0.46 \\
\hline DUCT & R4 & $53(0.63$ & 22459 & 844.0 & 21 & $1 .(02$ \\
\hline SPECFLR & R0/R 11 & 5() 5.97 & 20860 & 1598.5 & 134 & 3.43 \\
\hline WALL & R 19 & 478.48 & 19294 & 1566.2 & 243 & 6.33 \\
\hline SPECFLR & $\mathrm{R} 11 / \mathrm{R} 11$ & 423.73 & 16954 & 2340.0 & 388 & 6.77 \\
\hline ATTIC & R49BLOW & 373.83 & 14030 & 1589.8 & 333 & 8.53 \\
\hline VAULT & R38BLOW & 4()1.()4 & 15619 & 1334.6 & 234 & 7.16 \\
\hline WINDOW & VINYL & 328.61 & 11410 & 2619.0 & 1623 & 25.27 \\
\hline WINDOW & ARGON & 319.64 & 10898 & 512.8 & 218 & 17.30 \\
\hline SPECFLR & $\mathrm{R} 22 / \mathrm{R} 11$ & $3(55.34$ & 10260 & 637.5 & 388 & 24.84 \\
\hline WALL & R22 & 303.22 & 10139 & 120.7 & 84 & 28.54 \\
\hline SPECFLR & $\mathrm{R} 22 / \mathrm{R} 22$ & 297.47 & 9614 & 525.7 & 388 & 30.12 \\
\hline SYSTEM & HEATPUMP & 297.47 & 4680 & 4933.4 & 6.572 & 54.33 \\
\hline
\end{tabular}




\section{Marginal Cost Analysis for Climate Zone 1 \\ Cut-in Belly Blanket Insulation}

Location: SEATTLE, WASHINGTON

Base Case UA - 514.7

Base Case annual heating kWh - 12974

Base Case Component Specifications \& Nominal R-Values

HEATING SYSTEM: Electric Resistance

DUCT Unwrapped

INFILTRATION $0.35 \mathrm{ACH}$

DOOR R-5

WALL R-11

WINDOW R-1.33

FLOOR R-0 joist/R-7 belly blanket

ATTIC R-14

VAULT $R-14$

\begin{tabular}{|c|c|c|c|c|c|c|}
\hline Measure & & UA & kWh & dkWh & $\mathrm{dCos} t$ & mills \\
\hline DUCT & SOUND & 514.67 & 12561 & 413.7 & 10 & 0.99 \\
\hline DUCT & $\mathrm{R} 4$ & 514.67 & 12176 & 384.7 & 21 & 2.23 \\
\hline SPECFLR & $\mathrm{R}() / \mathrm{R} 11$ & 487.47 & 11047 & 1129.3 & 134 & 4.86 \\
\hline WALL & R19 & 459.98 & 100() 9 & 1037.7 & 243 & 9.55 \\
\hline SPECFLR & $\mathrm{R}() / \mathrm{R} 19$ & 432.69 & 8908 & 1100.6 & 284 & 10.52 \\
\hline ATTIC & R19 & 424.37 & 8608 & $3(0) .1$ & 98 & 13.36 \\
\hline VAULT & R19 & 416.05 & 8310 & 298.6 & 98 & 13.43 \\
\hline SPECFLR & $\mathrm{R}() / \mathrm{R} 22$ & 410.35 & 8090 & 219.1 & 105 & 19.47 \\
\hline ATTIC & R30 & 401.26 & 7767 & 323.3 & 2() 4 & 25.77 \\
\hline VAULT & R30 & 392.94 & 7472 & 294.7 & 234 & 32.46 \\
\hline SPECFLR & R()/R33 & 381.71 & 7052 & 420.8 & 388 & 37.65 \\
\hline WINDOW & VINYL & 336.49 & 5512 & 1539.9 & 1623 & $43 .(02$ \\
\hline WINDOW & ARGON & 327.52 & 5214 & 297.3 & 218 & 29.86 \\
\hline WALL & R22 & 325.4() & 5145 & 69.7 & 84 & 49.46 \\
\hline VAULT & R38BAF & 323.13 & 5070 & 74.2 & 136 & 74.88 \\
\hline ATTIC & R38 & $32(0.87$ & 4996 & 74.0 & 1.51 & 83.35 \\
\hline ATTIC & R49 & 317.84 & 4897 & 99.0 & 212 & 87.30 \\
\hline ATTIC & R52 & 317.09 & 4873 & 24.6 & 53 & 87.84 \\
\hline SYSTEM & HEATPUMP & 317.09 & 2269 & 2603.7 & 6.572 & 103.02 \\
\hline
\end{tabular}




\section{Marginal Cost Analysis for Climate Zone 2 \\ Cut-in Belly Blanket Insulation}

Location: SPOKANE, WASHINGTON

Base Case UA - 514.7

Base Case annual heating kWh - 19401

Base Case Component Specifications \& Nominal R-Values

HEATING SYSTEM: Electric Resistance

DUCT Unwrapped

INFILTRATION $0.35 \mathrm{ACH}$

DOOR R-5

WALL R-11

WINDOW R-1.33

FLOOR $R-($ ) joist/R-7 belly blanket

ATTIC R-14

VAULT R-14

\begin{tabular}{|c|c|c|c|c|c|c|}
\hline Measure & & UA & $\mathrm{kWh}$ & dkWh & $\mathrm{dCost}$ & mills \\
\hline DUCT & SOUND & 514.67 & 18789 & 612.3 & 10) & 0.67 \\
\hline DUC'T & R4 & 514.67 & 18208 & 581.3 & 21 & 1.47 \\
\hline SPECFLR & $\mathrm{R}(0 / \mathrm{R} 11$ & 487.47 & 16705 & 1503.2 & 134 & 3.65 \\
\hline WALL & R 19 & 459.98 & 1535() & 1354.0 & 243 & 7.32 \\
\hline SPECFLR & $\mathrm{R} 0 / \mathrm{R} 19$ & 432.69 & 13850 & 1500.1 & 284 & 7.72 \\
\hline ATTIC & R19 & 424.37 & 13451 & 399.4 & 98 & 10.04 \\
\hline VAULT & R19 & 416.05 & 13053 & 397.5 & 98 & 10.09 \\
\hline SPECFLR & $\mathrm{R}(0 / \mathrm{R} 22$ & 410.35 & 12758 & 295.9 & 105 & 14.42 \\
\hline ATTIC & R30) & 401.26 & 12326 & 431.4 & 204 & 19.31 \\
\hline VAULT & R30) & 392.94 & 11931 & 395.2 & 234 & 24.21 \\
\hline SPECFLR & $\mathrm{R}() / \mathrm{R} 33$ & 381.71 & 11356 & 574.6 & 388 & 27.57 \\
\hline WINDOW & VINYL & 336.49 & 9255 & 2101.1 & 1623 & 31.53 \\
\hline WINDOW & ARGON & 327.52 & 8843 & 412.6 & 218 & 21.51 \\
\hline WALL & R22 & 325.4() & 8745 & 97.2 & 84 & 35.48 \\
\hline VAULT & R38BAF & 323.13 & 8642 & 103.5 & 136 & 53.64 \\
\hline SYSTEM & HEATPUMP & 323.13 & 3975 & 4667.1 & 6572 & 57.48 \\
\hline ATTIC & R38 & 320.87 & 3934 & 41.2 & 151 & 149.70 \\
\hline ATTIC & R49 & 317.84 & 3878 & 55.1 & 212 & 156.69 \\
\hline ATTIC & R.52 & 317.09 & 3865 & 13.7 & 53 & \\
\hline
\end{tabular}


Marginal Cost Analysis for Climate Zone 3 Cut-in Belly Blanket Insulation

I. onation: Missoula, Montana

Base Case UA - 514.7

Base Case annual heating kWh - 22777

Base Case Component Specifications \& Noninal R-Values

HEATING SYSTEM: Electric Resistance

DUCT Unwrapped

INFILTRATION $0.35 \mathrm{ACH}$

DOOR R-5

WALL R-11

WINDOW R-1.33

FLOOR R-0 joist/R-7 belly blanket

ATTIC R-14

VAULT R-14

\begin{tabular}{|c|c|c|c|c|c|c|}
\hline Measure & & UA & kWh & dk Wh & dCost & mills \\
\hline DUCT & SOUND & 514.67 & 22070 & 707.2 & 10 & 0.58 \\
DUCT & R4 & 514.67 & 21392 & 678.1 & 21 & 1.26 \\
SPECFLR & R0/R11 & 487.47 & 19663 & 1729.1 & 134 & 3.17 \\
WALL & R19 & 459.98 & 18103 & 1560.1 & 243 & 6.35 \\
SPECFLR & R0/R19 & 432.69 & 16358 & 174.5 & 284 & 6.63 \\
ATTIC & R19 & 424.37 & 15895 & 463.2 & 98 & 8.66 \\
VAULT & R19 & $416 .(05$ & 15433 & 461.8 & 98 & 8.69 \\
SPECFLR & R0/R22 & 410.35 & 15088 & 345.0 & 105 & 12.36 \\
ATTIC & R30 & 401.26 & 14586 & 501.9 & 204 & 16.60 \\
VAULT & R30 & 392.94 & 14128 & 458.3 & 234 & 20.87 \\
SPECFLR & RO/R33 & 381.71 & 13460 & 667.7 & 388 & 23.73 \\
WINDOW & VINYL & 336.49 & $110(04$ & 2455.8 & 1623 & 26.98 \\
WINDOW & ARGON & 327.52 & 10523 & 481.6 & 218 & 18.43 \\
WALL & R22 & 325.40 & 10409 & 113.4 & 84 & 30.41 \\
VAULT & R38BAF & 323.13 & 10288 & 120.9 & 136 & 45.96 \\
SYSTEM & HEATPUMP & 323.13 & 4899 & 5389.4 & 6572 & 49.77 \\
ATTIC & R38 & 320.87 & 4850 & 49.4 & 151 & 125.02 \\
ATTIC & R49 & 317.84 & 4784 & 66.0 & 212 & 130.99 \\
ATTIC & R52 & 317.09 & 4767 & 16.4 & 53 & 131.74 \\
\hline
\end{tabular}


Marginal Cost Analysis for Climate Zone 1

Cut-in Belly Blanket Insulation

Heat Pump-Only

Location: SEATTLE, WASHINGTON

Base Case UA - 514.7

Base Case annual heating $\mathrm{kWh}$ - $\mathbf{5 2 0 3}$

Base Case Component Specifications \& Nominal R-Values

HEATING SYSTEM Heat Pump

DUCT Unwrapped

INFILTRATION $0.35 \mathrm{ACH}$

DOOR R-5

WALL R-11

WINDOW R-1.33

FLOOR R-0 joist/R-7 belly blanket

ATTIC R-14

VAULT R-14

\begin{tabular}{|c|l|l|l|l|l|l|}
\hline Measure & & UA & kWh & dkWh & dCost & mills \\
\hline DUCT & SOUND & 514.67 & 5059 & 143.7 & 10 & 2.84 \\
DUCT & R4 & 514.67 & 4922 & 137.1 & 21 & 6.25 \\
SPECFLR & R(0/R11 & 487.47 & 4533 & 389.4 & 134 & 14.08 \\
WALL & R19 & 459.98 & 4169 & 363.5 & 243 & 27.27 \\
SPECFLR & R0/R19 & 432.69 & 3770 & 399.4 & 284 & 28.99 \\
ATTIC & R19 & 424.37 & 3662 & 107.9 & 98 & 37.16 \\
VAULT & R19 & 416.05 & 3557 & 104.7 & 98 & 38.32 \\
SPECFLR & R0/R22 & 410.35 & 3478 & 79.2 & 105 & 53.84 \\
ATTIC & R30 & 401.26 & 3361 & 117.4 & 204 & 70.96 \\
VAULT & R30 & 392.94 & 3253 & 107.4 & 234 & 89.07 \\
SPECFLR & R0/R33 & 381.71 & 3099 & 154.2 & 388 & 102.72 \\
WINDOW & VINYL & 336.49 & 2517 & 581.7 & 1623 & 113.87 \\
WINDOW & ARGON & 327.52 & 2402 & 114.9 & 218 & 77.26 \\
WALL & R22 & 325.40 & 2375 & 27.1 & 84 & 127.39 \\
VAULT & R38BAF & 323.13 & 2346 & 28.9 & 136 & 192.47 \\
ATTIC & R38 & 320.87 & 2317 & 28.9 & 151 & 213.82 \\
ATTIC & R49 & 317.84 & 2279 & 38.7 & 212 & 223.41 \\
ATTIC & R52 & 317.09 & 2269 & 9.6 & 53 & 224.38 \\
\hline
\end{tabular}




\section{Marginal Cost Analysis for Climate Zone 2 \\ Cul-in Belly Blanket Insulation \\ lleat P'ump-()nly}

Location: SPOKANL, WASHINGTOON

Base Case UA - 514.7

Base Case annual heating kWh - 828()

Base Case Component Specifications \& Nominal R-Values

HEATING SYSTEM Heat Punp

DUCT Unwrapped

INFILTRATION ().35 ACH

DOOR R-5

WALL R-11

WINDOW R-1.3.3

FLOOR R-() joist/R-7 belly blanket

ATTIC R-1.4

VAULT R-14

\begin{tabular}{|c|c|c|c|c|c|c|}
\hline Measure & & $\mathbf{U A}$ & kWh & dkWh & $d \operatorname{cost}$ & mills \\
\hline DUCT & SOUND & 514.67 & 8017 & 262.9 & 10) & 1.55 \\
\hline DUCT & R4 & 514.67 & 7755 & 262.4 & 21 & 3.27 \\
\hline SPECFLR & $\mathrm{R}(\mathrm{l} / \mathrm{R} 11$ & 487.47 & 717.5 & 579.9 & 1.34 & 9.46 \\
\hline WALL & R 19 & 4.59 .98 & $6(0)()$ & 574.9 & 243 & 17.24 \\
\hline SPECFLR & $\mathrm{R}() / \mathrm{R} 19$ & 432.69 & 5001 & $6(09.6$ & 284 & 18.99 \\
\hline ATTIC. & $\mathrm{R} 19$ & 424.37 & 5867 & 123.7 & 98 & 32.43 \\
\hline VAUL'I & $\mathrm{R} 19$ & 416.05 & 5712 & 155.0 & 98 & 25.88 \\
\hline SPECFLR & $\mathrm{R}() / \mathrm{R} 22$ & 410.35 & 5593 & 118.9 & 105 & 35.89 \\
\hline ATTIC & R3() & 401.26 & 5420 & 173.2 & 204 & 48.11 \\
\hline VAULT & R3() & 392.94 & 5261 & 1.59 .1 & 234 & 60.13 \\
\hline SPECFLR & $R() / R .33$ & 381.71 & $5(1) 27$ & 233.6 & 388 & 67.82 \\
\hline WINDOW & VINYL & 336.49 & 4218 & 808.9 & 1623 & 81.89 \\
\hline WINDOW & $A R G O N$ & 327.52 & $4(055$ & 163.6 & 218 & 54.26 \\
\hline WAIL & R22 & 325.4() & 4016 & 38.6 & 84 & 89.24 \\
\hline VAULT & R38BAF & .323 .13 & .397 .5 & 41.2 & 136 & 134.78 \\
\hline ATIIC & R.38 & 320.87 & .39 .34 & 41.2 & 151 & 149.70 \\
\hline ATIIC & $\mathrm{R} 49$ & 317.84 & 3878 & 5.5 .1 & 212 & 156.69 \\
\hline AlTIC & R52 & 317.09 & 386.5 & 1.3 .7 & 53 & 157.41 \\
\hline
\end{tabular}


Marginal Cost Analysis for Climate Zone 3

Cut-in Belly Blankef Insulation

Ileat l'ump-()nly

Location: Missoula, Montana

Base Case UA - 514.7

Base Case annual heating $\mathrm{kWh}, \mathrm{I}$ ()()18,

Base Case Component Specifications \& Nominal R-Vallus

HEATING SYSTIEM Heat PUmp)

DUCT Unwrapped

INFILTRATION (). 35 ACH

DOOR R -5

WALL R-il

WINDOW R-1.33

FlOOOR R-() joist/R - 7 belly blankel

A'T"IIC R-14

VAUIT R.14

\begin{tabular}{|c|c|c|c|c|c|c|}
\hline Measure & & $1 \mathrm{IA}$ & $k W h$ & dkWh & dCost & mills \\
\hline DUCI & $S(O) N I)$ & .514 .67 & (9)7(1)8 & $3(5) .8$ & 10 & 1.32 \\
\hline DUC' & $\mathrm{RA}$ & 514.67 & (9)39.4 & 314.3 & 21 & 2.73 \\
\hline SPLCTIR & $R() / R \mid 1$ & 487.47 & 8721 & 67.3 .2 & 1.34 & 8.1 .5 \\
\hline WAIL & RI) & 4.59 .98 & $8(1.30$ & 681.4 & 243 & 14.5 .5 \\
\hline SPIECILR & $R() / R / 9$ & $4.32 .69)$ & 7.308 & $7.3(1.9$ & 28.4 & 1.5 .84 \\
\hline ATI'IC & 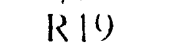 & 424.37 & 7167 & 1.11 .5 & 1) 8 & 28.34 \\
\hline VAUL'I' & Rlo & 416.10 .5 & $69 \times 2$ & 18.4 .5 & 98 & 21.74 \\
\hline SPIECILR & $R() / R 22$ & 410.35 & 0.830 & 142.9 & 105 & 29) 8.5 \\
\hline ATI'IC & $\mathrm{R} .30$ & 4() 1.20 & 60,32 & $2(1) 7.3$ & $2(1) 4$ & $4(0.19$ \\
\hline VAULT' & R.3() & 392.94 & 6412 & 189.7 & 2.34 & $.5(0.42$ \\
\hline SPECFLR & $R() / R 3.3$ & 381.71 & 016.3 & 279.3 & 388 & .56 .72 \\
\hline WINIOOW & VINYI. & 3.36 .49 & .5191 & 971.8 & 16.2 .3 & 68.17 \\
\hline WINIDOW & $\triangle R(I O N$ & .327 .52 & 4()$) 5$ & 190.5 & 218 & 45.17 \\
\hline WAIL & R22 & 325.4() & 40.18 & .70 .4 & 8.4 & 74.32 \\
\hline VAUIT & $\mathrm{R} .38 B \wedge \mathrm{I}$ & 323.13 & 4800 & 49.5 & 1.36 & 112.22 \\
\hline ATIIC & R.38 & .32() .87 & $.18 .5(1$ & 4).4 & 1.51 & $125 .(1)$ \\
\hline ATIIC & R49 & 317.8 .4 & 478.1 & $6(0.0)$ & $21 ?$ & 1.3() .99 \\
\hline ATIIS: & $\mathrm{R} .52$ & $.317 .(19)$ & .1767 & $16.4^{\prime}$ & 5.3 & 1.31 .7 .1 \\
\hline
\end{tabular}


9 Appendix C

Appendix C

Wall Framing Optimization Analysis 


\section{Marginal Cost Analysis for Climate Zone 1 Basic Run Wilh Wall Framing Change}

Locution: SEATTLE, WASIIINGTOON

Base Case UA - 5.34 .4

Base Case unnum heating kWh - 14(1),34

Base Case Component Specificallons \& Nominal R-Values

HEATING SYSTEM: Electric Resistance

DUCT Unwrapped

INFILTRATION (0,35 ACH

DOOR R-5

WALL R-11

WINDOW R-1.33

FLOOR R..() joist/R-7 belly blanket

ATTIC R-14

VAULT R-14

\begin{tabular}{|c|c|c|c|c|c|c|}
\hline Measure & & UA & $k W h$ & dlkWh & dC'ost & mills \\
\hline DUCT & SOUND & 534.41 & 1.3 .5() 2 & 5.32 .2 & 10 & 0.77 \\
\hline DUCT & R4 & 5.34 .41 & 13() 15 & 487.0 & 21 & 1.76 \\
\hline SPECFLR & $R() / R 11$ & 5() 9.75 & 11969 & 1045.9 & 134 & 5.24 \\
\hline SPECFLR & $\mathrm{R} 11 / \mathrm{R} 11$ & $455 .(0)$ & 10340 & 1628.7 & 388 & 9.73 \\
\hline ATTIC & R 19 & 446,68 & $10(0) 18$ & 322.2 & 98 & 12.45 \\
\hline VAULT & R 19 & 438.37 & 9698 & $32(0.0$ & 98 & 12.54 \\
\hline WALL & R19FC & 410.88 & 8650 & 1048.4 & 6() 2 & 23.43 \\
\hline ATTIC & R.30) & $4(01.79$ & 83() 6 & 343.4 & 204 & 24.26 \\
\hline VAULT & R30 & 393.47 & 7993 & 313.1 & 234 & 30.55 \\
\hline SPECFLR & $\mathrm{R} 22 / \mathrm{R} 11$ & 379.18 & 757() & 422.8 & 388 & 37.48 \\
\hline WINDOW & VINYL & 333.96 & $59(5)$ & 1661.4 & 1623 & 39.87 \\
\hline WINDOW & ARGON & 324.99 & 5588 & 320.8 & 218 & 27.68 \\
\hline WALL & R22FC & 322.87 & 5513 & 75.3 & 95 & 51.55 \\
\hline SPECFLR & $\mathrm{R} 22 / \mathrm{R} 22$ & 317.11 & 5217 & 295.6 & 388 & 53.59 \\
\hline VAULT & R38BAF & 314.85 & 5139 & 78.8 & 136 & 70.47 \\
\hline ATГIC & R.38 & 312.58 & 5() 60 & 78.7 & 151 & 78.40 \\
\hline ATIIC & $\mathrm{R} 49$ & 309.56 & 4954 & 105.4 & 212 & 82.00 \\
\hline ATTIC & R52 & $3(1) 8.81$ & 4928 & 26.2 & 53 & 82.44 \\
\hline SYSTEM & HEATPUMP & 308.81 & 23() 3 & 2625.6 & 6.572 & 102.17 \\
\hline
\end{tabular}




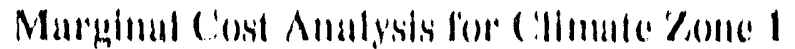

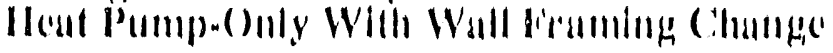

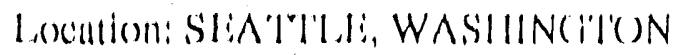

Buse Case UA - 534.4

base Case annuml healing kWh - 5.581

Buse Case Componeme Specillealoms \& Nomimal R-Values

HLATING SYSITEM: HeUI HUIM"

DUCT Unwrupped

INFILITRATIOS (0.35 ACIII

DOOR R-5

WALL, R-11

WINDOW R-1.33

HIOOOR R..() jolsi/R-7 belly blankel

ATITIC R-14"

VAULTR R-14

\begin{tabular}{|c|c|c|c|c|c|c|}
\hline Measure & & 111 & $k W /$ & llkWh & (IC.osi & mills \\
\hline DUC'I & $S()(1 N 1)$ & 5.34 .41 & 5.392 & 188.3 & 1() & 2.17 \\
\hline DUC'I' & $\mathrm{k} 1$ & 5.34 .41 & .5217 & 17.5 .6 & 21 & 4.88 \\
\hline SPLCIIR & R(V/KII & $5(19.75$ & 18.49 & .367 .3 & 1.34 & 14.93 \\
\hline SPLCIIR & $R|| / R||$ & $45.5 .(1)$ & $1.3(1)(0$ & .5 .19 .8 & 388 & 28.82 \\
\hline A'l'I'IC' & $R \mid Y$ & 446,68 & 418.5 & 114.2 & 98 & 3.5 .12 \\
\hline VAUI:I' & RIS & $4.38 . .37$ & $4(1) 72$ & 113.8 & () 8 & $3,5,26$ \\
\hline WAll. & R丨丿l & 410.88 & 3606 & .375 .5 & $(1) 2$ & 0.5 .42 \\
\hline A'T'IC. & $R .3()$ & $4(01.7(9)$ & 3.572 & $124.1)$ & 2()$\cdot 1$ & 67.21 \\
\hline VAUL'T & R.3() & 39.3 .47 & 3.450 & 11.3 .4 & 2.34 & 84.33 \\
\hline WINIOOW & VINYI. & 344.26 & 28.16 & 012.7 & 162.3 & $1(1) \times .12$ \\
\hline WINIOOW & $\operatorname{ARC}(\mathrm{I}) \mathrm{N}$ & 3.30 .28 & 2724 & 122.1 & 218 & 72.71 \\
\hline SPLECFIR & R22/R II & .324 .90 & 2.567 & 1.57 .0 & 388 & $10(1.94$ \\
\hline SPECTIR & $R 22 / R 22$ & 319.23 & 244 & 122.0 & .388 & 128.9() \\
\hline WAII. & R22li( & 317.11 & 2.11 .5 & 28.7 & 9.5 & 1.35 .34 \\
\hline 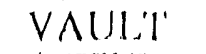 & R.3XBAl: & 314.85 & 2.385 & $3(1) .6$ & 136 & 181.26 \\
\hline A'TIK & R.38 & .312 .58 & 2.3 .54 & $3(1) .7$ & 1.51 & 2() 1.21 \\
\hline ATIIC & R49 & $3(1) .56$ & 2313 & 41.2 & 212 & $2(6), 80$ \\
\hline ATIIC & $R .52$ & 308.81 & 2.3() .3 & 10.3 & 5.3 & 210.61 \\
\hline
\end{tabular}




\section{Murginal const Amalysis f'or C.limate Zone 2 \\ Busic Run Will Wall linuming ('hange}

L, OCULIOI: SPOKANL, WASIIINGIION

Busc Case UA - 5.34 .4

Base Case annual heating $\mathrm{kWh}$ - $2(1) 844$

Base Case Component Specifleations de Nominal R-Values

HEATING SYSTIEM: Electric Resistance

DUC'T UnwrIIP)

INEILITRATION (0.35 AC.II

DOOR R-5

WNLL R-11

WINDOW R-1.33

Fl.OOR R-() joist/R-7 belly blanked

A'TIIC R.14

VAUL'T R-14

\begin{tabular}{|c|c|c|c|c|c|c|}
\hline Measure & & UA & $k W h$ & dkWh & dCost & mills \\
\hline DUC' & SOUND & 534.41 & 20061 & 78.3 .4 & 1() & (). .52 \\
\hline DUC'I & R4 & 534.41 & 19.32 .5 & 7.3 .5 .9 & 21 & 1.16 \\
\hline SPLCTLR & R(I)/R 11 & $5(4), 75$ & 179.32 & 1.392 .5 & 13.4 & 3.94 \\
\hline SPYECFI.R & $R\|/ R\|$ & $4.5 .5 .(1)$ & 159.34 & (i) () 8.4 & 388 & 7.93 \\
\hline A'TIIC & $R(0$ & 446,68 & 15508 & 425.7 & 98 & 9.42 \\
\hline VAUIIT & $R(G$ & 4.38 .37 & 1.508 .3 & 42.5 .4 & 98 & 9. 43 \\
\hline WALL & $\mathrm{R} ! 9 \mathrm{FC}$ & 410,88 & 1.3686 & 1.396 .5 & $6(1) 2$ & 17.59 \\
\hline A'TIIC & R.3() & 4() 1.70 & 1.3228 & 458.6 & 204 & 18.17 \\
\hline VAULT & $\mathrm{R} 3()$ & .393 .47 & 12808 & 42() .2 & 2.34 & 22.76 \\
\hline WINDOW & VINYI. & 348.26 & 10.5 .50 & 22.57 .5 & 162.3 & 29.34 \\
\hline WINDOW & $\triangle R G O N$ & 3.39 .28 & 10107 & 44.3 .0 & 218 & $2(0.04$ \\
\hline SPECFLR & R22/R II & 324.90 & 05.58 & 5.49 .7 & 388 & 28.8 .3 \\
\hline SPECTILR & $\mathrm{R} 22 / \mathrm{R} 22$ & 310.23 & 9()() & 467.0 & 388 & 33.88 \\
\hline WALL & R22ICC & 317.11 & 8987 & 10.3 .2 & 95 & 37.60 \\
\hline VAUL.'T' & R.38BAl: & 314.85 & 8877 & $1(x) .9$ & 1.30 & 5() .55 \\
\hline SYSIEM & HI:A'IPUMP & 314.85 & 4111 & 4766,2 & 6.572 & 50.28 \\
\hline A'Tl'IC' & R.38 & 312.58 & 4() 67 & 4.3 .6 & 1.51 & 141.66 \\
\hline ATIIC & R49) & $3(1) 9.56$ & $4(x)(1)$ & 58.3 & 212 & 148.15 \\
\hline ATIIC & RSS2 & $3(1) 8.81$ & 3004 & 14.5 & 53 & 148.93 \\
\hline
\end{tabular}


Marginal Cost Analysis for Climate Zone 2

Heat Pump.Only With Wall Framing Change

Location: SPOKANE, WASHINGTON

Base Case UA - 534.4

Base Case annual heating $\mathrm{kWh}$ - 8954

Base Case Component Specifications \& Nominul R-Values

HEATING SYSTEM: Heat Pump

DUCT Unwrapped

INFILTRATION $0.35 \mathrm{ACH}$

DOOR R-5

WALL R-11

WINDOW R-1.33

FLOOR R-0 joist/R-7 belly blanket

ATTIC R-14

VAULT R-14

\begin{tabular}{|c|c|c|c|c|c|c|}
\hline Measure & & UA & kWh & dkWh & dCost & mills \\
\hline DUCT & SOUND & 534.41 & 8576 & 377.8 & 10 & 1.08 \\
DUCT & R4 & 534.41 & 8239 & 336.7 & 21 & 2.55 \\
SPECFLR & R0/R11 & 509.75 & 7636 & 603.8 & 134 & 9.08 \\
SPECFLR & R11/R11 & 455.00 & 6909 & 727.0 & 388 & 21.79 \\
ATTIC & R19 & 446.68 & 6727 & 181.2 & 98 & 22.14 \\
VAULT & R19 & 438.37 & 6546 & 181.4 & 98 & 22.12 \\
WALL & R19FC & 410.88 & 5990 & 556.1 & 602 & 44.18 \\
ATTIC & R30 & 401.79 & 5807 & 183.0 & 204 & 45.52 \\
VAULT & R30 & 393.47 & 5678 & 128.9 & 234 & 74.21 \\
WINDOW & VINYL & 348.26 & 4766 & 912.0 & 1623 & 72.63 \\
WINDOW & ARGON & 339.28 & 4585 & 180.9 & 218 & 49.07 \\
SPECFLR & R22/R11 & 324.99 & 4383 & 202.6 & 388 & 78.22 \\
SPECFLR & R22/R22 & 319.23 & 4195 & 187.3 & 388 & 84.58 \\
WALL & R22FC & 317.11 & 4154 & 40.9 & 95 & 94.78 \\
VAULT & R38BAF & 314.85 & 4111 & 43.6 & 136 & 127.28 \\
ATTIC & R38 & 312.58 & 4067 & 43.6 & 151 & 141.66 \\
ATTIC & R49 & 309.56 & 4009 & 58.3 & 212 & 148.15 \\
ATTIC & R52 & 308.81 & 3994 & 14.5 & 53 & 148.93 \\
\hline
\end{tabular}




\section{Marginal Cost Amalysis for Cllmate Zone 3 Basic Run Wilh Wall Framing Change}

Location: Missoula, Montana

Base Case UA - 534.4

Base Case annual heating $\mathrm{kWh}$ - 24429

Base Case Component Specifications \& Nominal R-Values

HEATING SYSTEM: Electric Resistince

DUCT' Unwrapped

INFILTRATION $0.35 \mathrm{ACH}$

DOOR R-5

WALL R-11

WINDOW R-1.33

FL.OOR R-() joist/R-7 belly blankel

ATTIC R-14

VAULT R-14

\begin{tabular}{|c|c|c|c|c|c|c|}
\hline Measure & & UA & kWh & dlkWh & $\mathrm{dCost}$ & mills \\
\hline DUCT & SOUND & 534.41 & 23526 & 9() 2.7 & 10 & 0.45 \\
\hline DUCT & R4 & 534.41 & 22675 & 851.1 & 21 & $1 .() 1$ \\
\hline SPECILR & $\mathrm{R}() / \mathrm{R} \| 1$ & 5() 9.75 & 21075 & 150999 & 134 & 3.43 \\
\hline SPECFLR & $\mathrm{R}\|\mathrm{I} / \mathrm{R}\|$ & $4.5 .5 .(1)(0)$ & 18801 & 2274.8 & 388 & 6.97 \\
\hline А TTIC & R19 & 446.68 & 18310 & 491.1 & 98 & 8.17 \\
\hline VAULT & $R 19$ & 4.38 .37 & 17818 & 491.1 & 98 & 8.17 \\
\hline WALL & R19FC & 410.88 & 16197 & 1621.2 & $6(1) 2$ & 15.15 \\
\hline ATTIC & R3() & $4(1) 1.79$ & 1.5664 & 533.6 & $2(1) 4$ & 15.61 \\
\hline VAULT & R30) & 393.47 & 15176 & 487.6 & 234 & 19.62 \\
\hline WINDOW & VINYL & 348.26 & 12543 & 2633.3 & 1623 & 25.16 \\
\hline WINDOW & ARGON & 339.28 & 12() 24 & 518.6 & 218 & 17.12 \\
\hline SPECFLR & $\mathrm{R} 22 / \mathrm{R} 11$ & 324.99 & 11389 & 635.5 & 388 & 24.93 \\
\hline SPECFLR & $\mathrm{R} 22 / \mathrm{R} 22$ & 319.23 & 10834 & 5.5 .5 .1 & 388 & 28.54 \\
\hline WALL & $\mathrm{R} 22 \mathrm{FC}$ & 317.11 & $10 \% / 14$ & 119.9 & 95 & 32.36 \\
\hline VAUL.T & R38BAF & 314.85 & 10586 & 127.6 & 136 & 43.53 \\
\hline ATTIC & R38 & 312.58 & 10459 & 127.1 & 1.51 & 48.5 .5 \\
\hline SYSTEM & HEATPUMP & 312.58 & 5() 27 & 54.31 .7 & 6.572 & 49.39 \\
\hline ATTIC & $\mathrm{R} 49$ & $3(19.56$ & 4958 & 69.5 & 212 & 124.29 \\
\hline ATTIC & R.52 & 3()$\times .81$ & 4941 & 17.3 & 53 & 125.03 \\
\hline
\end{tabular}




\section{Marginal Cost Analysis for Climate Zone 3 Heat Pump-(Only With Wall Framing Change}

Location: Missoula, Montana

Base Case UA - 530.6

Base Case annual heating kWh - 24198

Base Case Component Specifications \& Nominal R-Values.

HEATING SYSTEM: Heat Pump

DUCT Unwrapped

INFILTRA'TION $0.35 \mathrm{ACH}$

DOOR R-5

WALL R $\cdots 11$

WINDOW R-1.33

FLOOR R-() joist/R-7 belly blanket

ATTIC R-14

VAULT R-14

\begin{tabular}{|c|c|c|c|c|c|c|}
\hline Measure & & UA & kWh & dkWh & dCost & mills \\
\hline DUCT & SOUND & $53(0.63$ & $233(1) 3$ & 895.6 & 10 & 0.46 \\
DUCT & R4 & 530.63 & 22459 & 844.0 & 21 & 1.02 \\
SPECFLR & R(0/R11 & $5(55.97$ & 20860 & 1598.5 & 134 & 3.43 \\
WALL & R19 & 478.48 & 19294 & 1566.2 & 243 & 6.33 \\
SPECFLR & R11/R11 & 423.73 & 16954 & 2340.0 & 388 & 6.77 \\
ATTIC & R49BLOW & 401.81 & 15665 & 1289.1 & 333 & 10.53 \\
VAULT & R38BLOW & 389.70 & 14956 & 7099.1 & 234 & 13.49 \\
WINDOW & VINYL & 344.48 & 12325 & 2631.1 & 1623 & 25.18 \\
WINIOOW & ARGON & 335.51 & 11807 & 517.7 & 218 & 17.15 \\
SPECFLR & R22/R11 & 321.22 & 11170 & 637.0 & 388 & 24.87 \\
WALL & R22 & 319.10 & 11048 & 121.9 & 84 & 28.29 \\
SPECFLR & R22/R22 & 313.34 & 10502 & 546.6 & 388 & 28.99 \\
SYSTEM & HEATPUMP & 313.34 & $5(1) 45$ & 5456.8 & 6572 & 49.16 \\
\hline
\end{tabular}



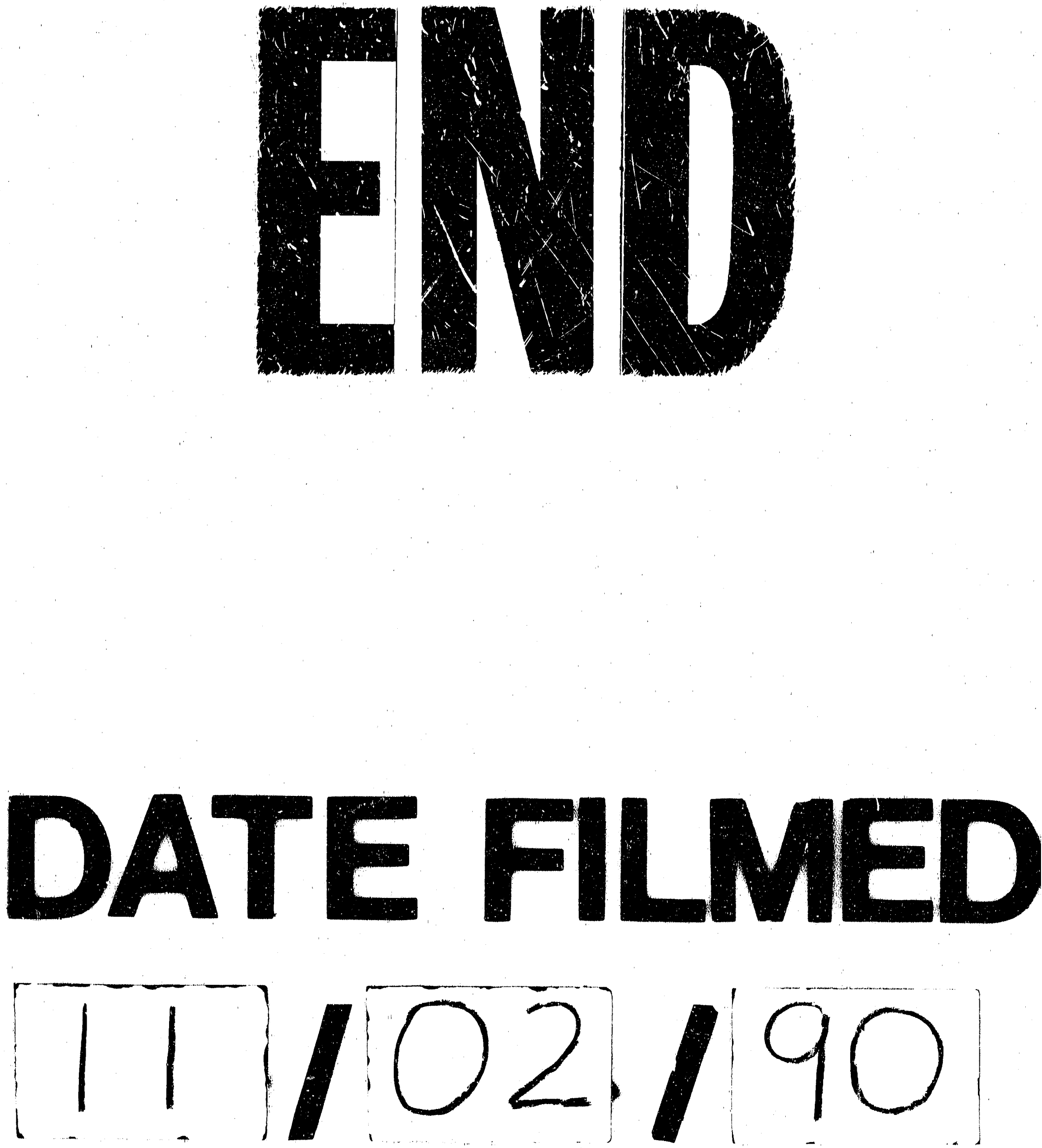
